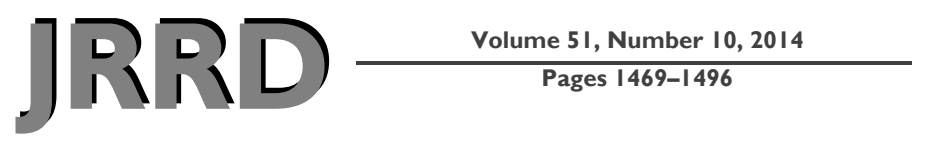

\title{
Benefits of microprocessor-controlled prosthetic knees to limited community ambulators: Systematic review
}

\author{
Andreas Kannenberg, MD, PhD; ${ }^{1 *}$ Britta Zacharias, Dipl-Ing (FH), CPO; ${ }^{2}$ Eva Pröbsting, Dipl-Ing (FH), CPO \\ ${ }^{1}$ Medical Affairs, Otto Bock HealthCare LP, Austin, TX; ${ }^{2}$ Clinical Research and Services, Otto Bock HealthCare \\ GmbH, Duderstadt, Germany
}

\begin{abstract}
The benefits of microprocessor-controlled prosthetic knees (MPKs) have been well established in community ambulators (Medicare Functional Classification Level [MFCL]-3) with a transfemoral amputation (TFA). A systematic review of the literature was performed to analyze whether limited community ambulators (MFCL-2) may also benefit from using an MPK in safety, performance-based function and mobility, and perceived function and satisfaction. We searched 10 scientific databases for clinical trials with MPKs and identified six publications with 57 subjects with TFA and MFCL-2 mobility grade. Using the criteria of a Cochrane Review on prosthetic components, we rated methodological quality moderate in four publications and low in two publications. MPK use may significantly reduce uncontrolled falls by up to $80 \%$ as well as significantly improve indicators of fall risk. Performance-based outcome measures suggest that persons with MFCL-2 mobility grade may be able to walk about $14 \%$ to $25 \%$ faster on level ground, be around $20 \%$ quicker on uneven surfaces, and descend a slope almost 30\% faster when using an MPK. The results of this systematic review suggest that trial fittings may be used to determine whether or not individuals with TFA and MFCL-2 mobility grade benefit from MPK use. Criteria for patient selection and assessment of trial fitting success or failure are proposed.
\end{abstract}

Key words: community ambulator, limited community ambulator, Medicare Functional Classification Level-2, microprocessor-controlled knees, mobility, MPK, non-microprocessorcontrolled prosthetic knees, perceived function, performancebased function and mobility, safety, transfemoral amputation.

\section{INTRODUCTION}

Absence or amputation of a lower limb may be the life-altering consequence of congenital deficiency, trauma, malignancy, peripheral vascular disease, diabetic neuropathy, and other conditions. The risk of leg amputation increases with age for all etiologies; however, vascular disease accounts for up to 82 percent of lower-limb amputations [1]. A more proximal amputation results in greater physical and functional impairment to the individual, including a decreased likelihood of regaining household or community ambulation and an increased

\footnotetext{
Abbreviations: $2 \mathrm{MWT}=2$-min walk test, $\mathrm{ABC}=$ Activityspecific Balance Confidence Scale, ADL = activity of daily living, $\mathrm{AMP}=$ Amputee Mobility Predictor, $\mathrm{GRF}=$ ground reaction force, $\mathrm{ICR}=$ instantaneous center of rotation, $\mathrm{LCI}=$ Locomotor Capabilities Index, MDC $=$ minimal detectable change, MFCL $=$ Medicare Functional Classification Level, $\mathrm{MP}=$ microprocessor, $\mathrm{MPK}=$ microprocessor-controlled prosthetic knee, NMPK = non-microprocessor-controlled prosthetic knee, PEQ = Prosthesis Evaluation Questionnaire, RCT = randomized controlled trial, TFA = transfemoral amputation, TUG = Timed "Up and Go" test.

*Address all correspondence to Andreas Kannenberg, MD, PhD; Otto Bock HealthCare LP, Riata Business Park, Building 8, Suite 250, 12365-B Riata Trace Pkwy, Austin, TX 78727; 763-489-5105; fax: 763-519-6153. Email: andreas.kannenberg@ottobock.com http://dx.doi.org/10.1682/JRRD.2014.05.0118
} 
risk of falling in subjects with above-knee as compared with below-knee amputation [2-13]. According to a consolidation of recent epidemiological studies, the population of people with above-knee limb loss living in the United States may be as large as 400,000 [14-15].

Adequate selection of prosthetic components is one of the key processes to achieving the best possible rehabilitation outcomes. In subjects with transfemoral amputation (TFA), the prosthetic knee is a very important component tasked with restoring knee biomechanics while at the same time providing maximum stability and safety [16-19]. In the early 1990s, Medicare adopted the Medicare Functional Classification Levels (MFCLs), which are used to rate the person with amputation's ability and/or potential ability to ambulate. Shortly thereafter, based on the prosthetic knees available at that time, Medicare developed coverage criteria (indications/limitations and/or medical necessity) for prosthetic knees that were adapted to the MFCL. Medicare's prosthetic knee coverage criterion has not been modified since its inception and remains in effect today (Table 1) [20]. Additionally, the MFCL and coverage criteria have also been adopted by many third-party payors [21]. Fluid stance control mechanisms available at that time were correctly considered too difficult to be safely operated by lowerfunctioning individuals, and the remaining traditional stance control mechanisms offered similar levels of inherent stability and support of function [16,22]. As a result, the coverage criteria for prosthetic knees were based on the ability and/or potential ability of subjects to vary cadence and walking speed as the decisive criterion for the selection of an appropriate swing control technology. As a consequence of these criteria, fluid control prosthetic knee mechanisms, regardless of their use for stance or swing control, have been reserved for usually younger persons with amputation of the higher MFCL-3 and MFCL-4 mobility grade.

In the past $15 \mathrm{yr}$, prosthetic technology has progressed to microprocessor (MP)-controlled fluid stance as well as stance and swing control mechanisms to overcome the inverse relationship between stability and support of function inherent in non-MP-controlled prosthetic knees (NMPKs). Clinical research, mainly conducted in the unlimited community ambulator (MFCL-3) population with low to moderate methodological quality, has

Table 1.

Definition of Medical Function Classification Level (or K-levels) and Medicare Guidelines for Covered Prostheses by K-level of mobility [20].

\begin{tabular}{llr}
\hline K-Level & Description & Medicare Reimbursed Prosthesis \\
\hline K0 & Nonambulatory: "Does not have the ability or potential & None
\end{tabular}
to ambulate or transfer safely with or without assistance and a prosthesis does not enhance quality of life or mobility."

K1 Household Ambulator: "Has the ability or potential to use a prosthesis for transfers or ambulation on level surfaces at fixed cadence.”

K2 Limited Community Ambulator: "Has the ability or potential for ambulation with the ability to traverse low-level environmental barriers such as curbs, stairs, or uneven surfaces.”

K3 Unlimited Community Ambulator: "Has the ability or potential for ambulation with variable cadence. Typical of the community ambulator who has the ability to traverse most environmental barriers and may have vocational, therapeutic, or exercise activity that demands prosthetic utilization beyond simple locomotion."

K4 Very Active: "Has the ability or potential for prosthetic ambulation that exceeds the basic ambulation skills, exhibiting high impact, stress, or energy levels, typical of the prosthetic demands of the child, active adult, or athlete.”

Constant Friction Knee

Constant Friction Knee

Fluid Control Knee, Non-MP or MP-Controlled Knee

Fluid Control Knee, Non-MP or MP-Controlled Knee 
demonstrated improved safety and superior function of MP-controlled prosthetic knees (MPKs) [23] in level walking [24-30], walking on uneven terrain [24-26,31$32]$, walking on slopes [21,26,33-34], walking on stairs $[25,31,35]$, and stumble recovery [24-25], resulting in significantly reduced numbers of stumbles and falls and improved balance than with NMPKs [24-26,31,34,36].

With current coverage criteria restricting the provision of advanced prosthetic technology to usually younger, healthier, higher-functioning individuals, lowerlimb prosthetics finds itself on a different pathway than other fields of healthcare. Typically, most advanced healthcare technologies serve the oldest, sickest, and most restricted patients, as reflected by the fact that 80 percent of lifetime healthcare expenditures are incurred in the second half of life [37] with a substantial share of these accruing in the last year before death [3840]. Today, the majority of patients undergoing a TFA are over the age of $65 \mathrm{yr}[1,41-43]$ and do not reach the level of unlimited community ambulation [13] using the prosthetic knees covered under current Medicare criteria, which are simple in technology, limited in function, and often developed decades ago. These findings raise the question whether limited community ambulators (MFCL-2) may also benefit more from using MPKs than from NMPKs as has been demonstrated in unlimited community ambulators (MFCL-3). We therefore conducted a systematic review of randomized and nonrandomized clinical trials comparing the effects of NMPK and MPK interventions in limited community ambulators (MFCL-2) with a unilateral TFA in three clinically meaningful areas.

First, falling is a major issue in this population [8,4445], and recurrent falls and fear of falling are associated with functional limitations and deterioration in balance, coordination, and endurance, resulting in activity avoidance and decreased independence and mobility [46-50]. Falling and its detrimental consequences pose serious clinical challenges for persons with amputation, especially elderly, lower-functioning individuals who often experience various comorbidities and physical deconditioning [44-45]. Therefore, the evaluation of performance-based and self-reported outcome measures would help assess the effect of MPK use on the safety of ambulation with the prosthesis.

Second, the goal of rehabilitation is to enable patients to resume a lifestyle as independent as possible. Therefore, the analysis of performance-based function and mobility to appraise the person with amputation's ability to perform household activities of daily living (ADLs) and activities required for community ambulation (e.g., walking on uneven terrain, slopes, and stairs) would allow for drawing conclusions on the effects of MPK use on function and overall mobility as indicators or prerequisites for an independent lifestyle and participation.

Third, the perception of function and satisfaction plays an important role on the behavior of patients, such as taking on or avoiding ADLs [9,46-47,51-54]. Thus, the evaluation of self-reported measures to assess perceived safety, function, and satisfaction with prosthesis use may allow for judging whether MPK use may create the basis for behavioral changes such as a more selfdependent lifestyle and an increase in general ambulation activity.

The specific outcome measures representing each clinical area of interest were defined a priori and are described in detail in the "Inclusion Criteria" section.

\section{METHODS}

\section{Search Strategy}

The systematic search of publications was conducted on October 28 and 29, 2013, using the scientific literature databases Medline, EMBASE, and PsychInfo (all three accessed via DIMDI [German Institute for Medical Documentation and Information]); DARE; Cirrie; CINAHL; Cochrane Library; OTseeker; PEDro; and RECAL Legacy. The databases were searched with terms related to MPKs and individuals with a unilateral TFA and MFCL2 mobility grade. The search terms were combined into a title, abstract, and key word search phrase using Boolean operators, resulting in the following syntax:

1. Unilateral.

2. Femoral.

3. Transfemoral.

4. Above?knee.

5. Through?knee.

6. Knee?disarticulation.

7. Or/2-6.

8. Amput*.

9. Prosth*.

10. Or/8-9.

11. Microprocessor.

12. MP*. 
13. Or/11-12.

14. Knee.

15. And/1,7,10,13,14.

The literature search was not extended to study types or specific outcome measures but limited to English- and German-language publications with no limit on the date of publication. In addition, the references of the analyzed full-text publications were searched for additional pertinent published studies.

\section{Screening}

The titles and abstracts of the publications found were independently screened by two authors (A.K. and B.Z.) with regard to inclusion and exclusion criteria to classify them as relevant, not relevant, or possibly relevant. Full articles were reviewed for all publications classified as relevant or possibly relevant. Disagreements on references of possible relevance were settled by third author (E.P.) review, and joint discussion of full-text articles occurred among all three authors for final agreement on the classification of relevance of the article.

\section{Inclusion Criteria}

Inclusion criteria included-

1. Randomized or nonrandomized comparative study that includes a prosthetic knee intervention with comparison of results of an MPK with those of one or more NMPKs.

2. Study that reports results of individuals with a unilateral TFA or knee disarticulation classified as MFCL-2 mobility grade either as the target study group, as a subgroup analysis, or as raw data that permits a post hoc analysis of the MFCL-2 subgroup of the study sample.

3. Study that uses and reports quantifiable results of objective and/or self-reported outcome measures in the areas of safety, function and mobility, and perceived function and satisfaction with the prosthesis. The included studies were explicitly screened for, but not limited to, the following outcome measures as validated representatives for the areas of clinical interest of this review:

a. Safety: Outcomes measures validated for assessing the risk of falling in individuals with lower-limb amputation, such as the self-reported number of stumbles and falls within a defined period of time [55-56], Timed "Up and Go" test (TUG) [57-61], Four Square Step Test [62], Berg Balance Scale
[63-64], obstacle avoidance test [65], Activityspecific Balance Confidence Scale (ABC) [6,6668], Locomotor Capabilities Index (LCI) advanced score [62], and Prosthesis Evaluation Questionnaire (PEQ) Addendum [34].

b. Performance-based function and mobility: MFCL classification if determined with all prosthetic interventions and validated outcome measures that objectively assess the physical abilities of subjects with lower-limb amputation, such as the Amputee Mobility Predictor (AMP) with and without prosthesis [69], timed walk tests on level ground [7071] and uneven terrain [31], the Assessment of Daily Activity Performance in Transfemoral Amputees test for assessing performance in ADLs [72], divided attention tests while walking [34], performance and gait characteristics in slope and stair negotiation such as the Hill and Stair Assessment Indices [34], motion analysis [24,35,73-74], or the Montreal Rehabilitation Performance Profile [31,75].

c. Perceived function and satisfaction: Validated selfreported outcome measures such as the PEQ [7677], Orthotic and Prosthetic Users' Survey [78], LCI [79-80], Amputee Activity Score [81], Functional Measure for Amputees [82-83], Houghton Scale [82,84-85], Prosthetic Profile of the Amputee [82], Orthotics and Prosthetics National Outcomes Tool [82,86], Special Interest Group in Amputation Medicine score [87], and Trinity Amputation and Prosthesis Experience Scales [88-89].

\section{Exclusion Criteria}

Exclusion criteria included-

1. Studies with implantable knee joints (total knee arthroplasty or replacement).

2. Studies with patients with a bilateral amputation or an amputation level higher than transfemoral or lower than knee disarticulation.

3. Studies that only report opinions or judgments of the authors but no data that allow for an independent reappraisal.

4. Duplicate article.

\section{Assessment of Methodological Quality}

After screening and sorting articles for pertinence to the subject of this review, methodological quality and risk of bias were separately assessed by two authors 
(A.K. and B.Z. or E.P.) using the checklist of a Cochrane Systematic Review on prosthetic ankle-foot mechanisms published by Hofstad et al. [90]. It is based on two existing scales for methodological quality assessment of randomized controlled trials (RCTs) of van Tulder et al. [91] and Verhagen et al. [92] but was adapted to also evaluate internal and external validity as well as the risk of bias of nonrandomized studies as recommended by Downs and Black [93], Reisch et al. [94], and Zaza et al. [95]. We are not aware of any RCTs in prosthetic research, which is confirmed by the results of a recent systematic review of the entire prosthetic literature [96]. We therefore believe that the scale of Hofstad et al. [90], accepted by the Cochrane Collaboration, is an appropriate tool to assess the methodological quality of clinical trials in prosthetics. The Hofstad checklist comprises 13 criteria for methodological quality that are all scored using one out of three possible levels: no $=0$, yes $=1$, or not applicable.

\section{Criteria for Methodological Quality}

\section{Selection of Patients}

A1. Adequate description of inclusion and exclusion criteria (with a minimum of three of the following descriptors: age, amputation level, etiology, level of activity, time since amputation, residual limb condition, comorbidities, and sex)?

A2. Homogeneity of the study groups (at least for age, etiology and level of the amputation, and mobility grade)?

A3. Prognostic comparability of the study sample (e.g., for etiology and level of amputation, age, sex, condition of the residual limb, comorbidities, etc.; prognostic comparability is given by definition in within-subject studies with every patient acting as his or her own control)?

A4. Randomization (randomized order of intervention: 1 point, randomization of patients to intervention and control groups [RCT]: 2 points)?

\section{Intervention}

B5. Description of experimental intervention (can the study be repeated)?

B6. Control of cointerventions?

B7. Blinding of patients and/or assessors?

B8. Timing of measurement (adequate adaptation)?

B9. Appropriateness of outcome measures to answer the research question of the study?
Statistical Validity

C10. Attrition rate not exceeding 20 percent?

C11. Adequate sample size (sample size calculation and power analysis)?

C12. Intention-to-treat analysis?

C13. Data presentation (point estimates and measures of variability)?

The rules for scoring the individual criteria were reported in detail by Hofstad et al. [90] and have been strictly followed for this review.

\section{Rating of Methodological Quality According to Hofstad et al. [90]}

A grade (high quality). Minimum of 11 points in total, with at least 6 points in the patient selection (A) and intervention (B) criteria with valid scores in blinding (B7) and accommodation (B8).

B grade (moderate quality). Minimum of 6 points in total, with at least 6 points in the patient selection (A) and intervention (B) criteria with a valid score in accommodation (B8).

C grade (low quality). Minimum of 6 points in total, with at least 6 points in the patient selection (A) and intervention (B) criteria with invalid scores in blinding (B7) and accommodation (B8).

Studies with a total score of less than 6 points were considered to have insufficient quality to be included in this systematic review.

\section{Data Extraction}

Data extraction from each study included was conducted independently by two reviewers (A.K. and B.Z. or E.P.) using a standardized, self-developed data extraction form that covered the design of the study; inclusion and exclusion criteria, number, age, and sex of the patients; the level and etiology of the amputation; type and severity of comorbidities; control and study intervention; concurrent therapies and other potential confounders; follow-up times; outcome measures and their results for every study group; raw data of individual patients, if reported; and the results of statistical comparisons between the study groups ( $p$-values, confidence intervals, etc.). The outcome measures were grouped according to the predefined areas of safety, performance-based function and mobility, and perceived function and satisfaction as described in detail in the "Inclusion Criteria" section.

Because the variability of patient characteristics within the MFCL-2 mobility grade is broad, an attempt was 
made to stratify the subjects based on two well-validated objective measures of the overall physical capabilities, the AMP [69] and the walking speed in timed walk tests [70-71,97] on the NMPK, because such stratification might possibly allow for relating differing results to different levels of physical capabilities and thus help guide appropriate component selection.

\section{Post Hoc Analyses, Data Pooling, and Meta-Analyses}

Raw data of all subjects allowing for a post hoc statistical analysis of the MFCL-2 subgroup was reported by one study included in this review [31]. In another study, individual results of the AMP were reported but not statistically analyzed for the different functional level subgroups [21]. Due to the low patient numbers of $n=9$ [31] and $n=8$ [21], the post hoc statistical analyses were conducted using the Wilcoxon signed rank test with a power of 80 percent in WinSTAT for Excel (Microsoft Corporation; Redmond, Washington). Differences between interventions with a $p<0.05$ were considered statistically significant.

Due to inhomogeneity in study designs, patient numbers, acclimation times, and outcome measures assessed, data pooling and meta-analyses were not suitable.

\section{RESULTS}

\section{Literature Search}

The literature search found 986 citations in all databases used. A total of 412 duplicates were identified and eliminated. Based on a review of the article titles, 501 publications were excluded as not pertinent. Then, the abstracts of the remaining 73 articles were analyzed to classify 46 as not pertinent, leaving 27 publications for full-text review, after which a further 20 publications were excluded as not pertinent (Figure). No additional pertinent citations were found in the references of the full-text articles. Thus, the literature search ultimately revealed seven publications on five clinical trials with subjects with a unilateral TFA and MFCL-2 mobility grade. Two clinical trials resulting in four publications exclusively studied individuals with MFCL-2 mobility grade [98-101], two studies reported subgroup analyses of MFCL-2 subjects [21,102], and one study reported individual raw data that permitted a post hoc analysis of the MFCL-2 subgroup [31]. Three studies investigated the effects of the MP stance and swing controlled C-Leg

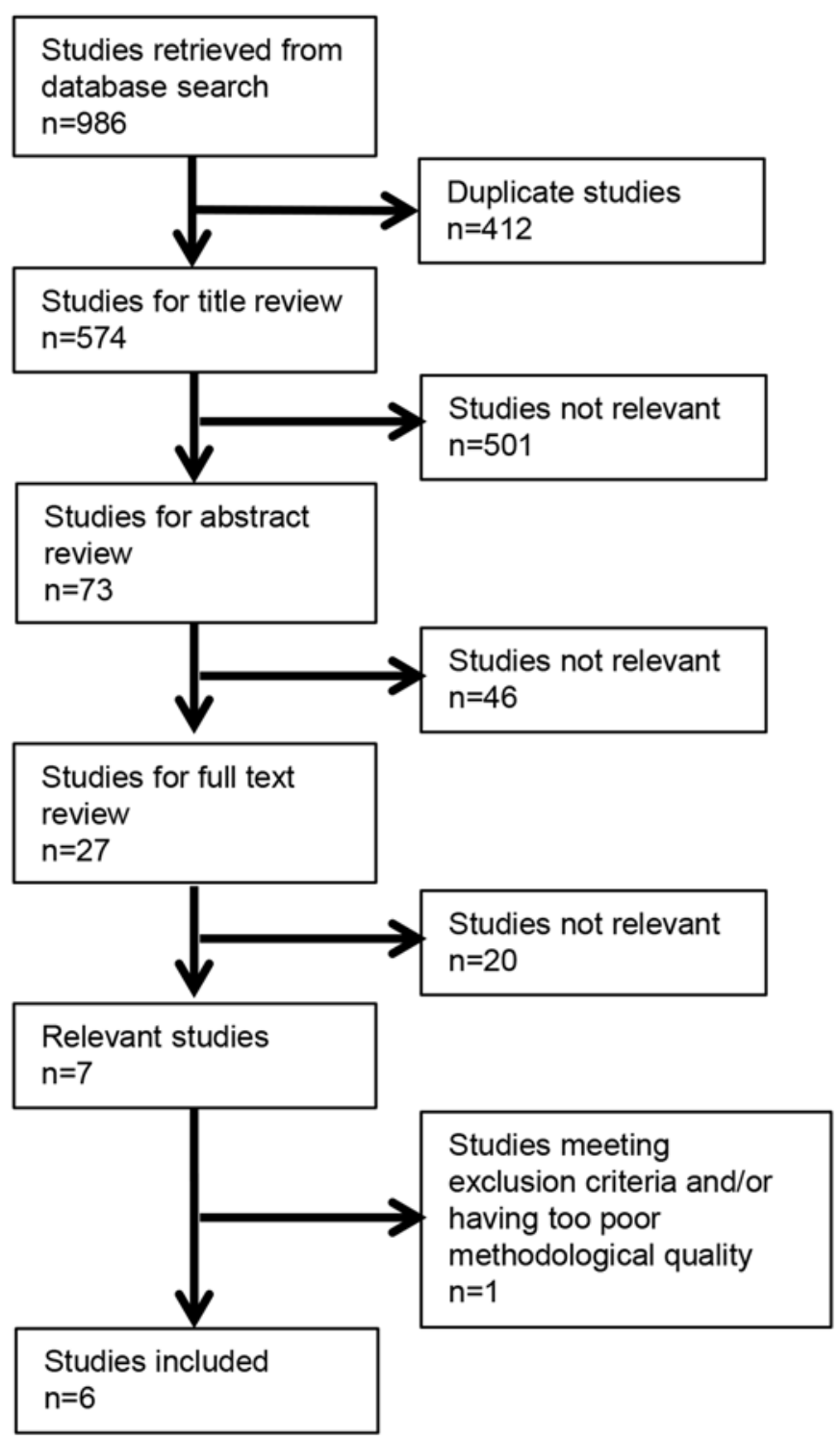

Figure.

Flowchart of literature search and analysis.

[21,31,102], one study investigated the MP stance controlled C-Leg Compact [100-101], and one study investigated both the C-Leg and C-Leg Compact in randomized order [98-99].

\section{Assessment of Methodological Quality}

As expected, we have not been able to identify an RCT with MPKs in individuals with a unilateral TFA and MFCL-2 mobility grade. The German-language publication of Wetz et al. had to be excluded from further analysis 
because it met predefined exclusion criterion number 3 [102]. This article only reported qualitative judgments of the authors on the benefits of individual subjects from using an MPK as compared with their existing NMPK after a $1 \mathrm{~d}$ trial fitting that did not allow for an independent reappraisal of the results. Nevertheless, it was included in the assessment of methodological quality, where it was found to not attain the minimum score to be included in further analyses. For the other six relevant publications identified in the literature search, methodological quality was rated B (moderate) in four articles and $\mathrm{C}$ (low) in two articles (Table 2).

Moreover, a methodological uncertainty of all studies was the determination of the MFCL of the individuals. In all studies, only the everyday clinical practice of subjective judgment of the prosthetist and/or physical therapist was used to assign the subjects to a certain MFCL. No study used a reproducible method such as the AMP [69] or the walking speed in timed walk tests $[69,97]$ to support this determination. One study assessed the AMP but did not use it to determine the mobility grade [21]. The individual AMP values ranged from 34 to 41, with most values exceeding 36 , the currently recommended upper cutoff for MFCL-2. However, in the original publication of Gailey et al., the mean and standard deviation of AMP values across the MFCL-2 patient sample was $34.65 \pm$ 6.49, with a range of 19 to 41 [69]. The other studies assessed the fastest possible walking speed in timed walk tests [31,98-99] or during motion analysis [100-101]. Because a walking distance of up to $150 \mathrm{~m}$ in the 2-min walk test (2MWT) (equals a walking velocity of up to $4.5 \mathrm{~km} / \mathrm{h}$ or $1.25 \mathrm{~m} / \mathrm{s}$ ) is still indicative of limitations of the overall walking capabilities [97], the assignment of the patients studied to the MFCL-2 mobility grade appears justified. Table 3 describes the demographics of the 57 subjects included in the six studies as well as the NMPKs used at the time of enrollment and as controls.

\section{Stratification of Subjects With Medicare Functional Classification Level-2 Mobility Grade}

Because only one of the four studies (six publications) reviewed had assessed the AMP, this measure could not be used for a stratification of subjects. One study used the walking speed in the 2MWT as one component for the stratification of the subjects into low, intermediate, and high subgroups [98-99]. The other component, daily activity, had not been assessed in the other studies, but the walking distance or speed in the 2MWT has been shown to correlate well with daily activity [97]. For this reason, the fastest possible walking speed with the NMPK was used to relate the results of three publications [31,100-101] to those of the study that had stratified its sample [98-99] as the best possible approximation. Based on the heterogeneity of the walking speed ranges in the study samples, no a priori subgroups across all studies and outcomes could be created. However, the relationship between the fastest possible walking speed on the NMPK and the results in the different outcome categories when using an MPK allow for interesting conclusions.

\section{Safety Outcomes}

Three studies with a total of 27 limited community ambulators reported outcome measures related to safety

Table 2.

Quality rating of five studies according to criteria of Cochrane review of Hofstad et al. [90].

\begin{tabular}{|c|c|c|c|c|c|c|c|c|c|c|c|c|c|c|c|c|c|}
\hline Study & A1 & A2 & A3 & A4 & B5 & B6 & B7 & B8 & B9 & C10 & C11 & C12 & C13 & $\begin{array}{c}\text { Total: A + B } \\
\text { Criteria }\end{array}$ & $\begin{array}{l}\text { Total: C } \\
\text { Criteria }\end{array}$ & $\begin{array}{l}\text { Total: A + B } \\
\text { + C Criteria }\end{array}$ & $\begin{array}{l}\text { Overall } \\
\text { Grade }\end{array}$ \\
\hline $\begin{array}{l}\text { Wetz et al., } 2005 \\
\text { [102] }\end{array}$ & 0 & 1 & 1 & 0 & 0 & 1 & 0 & 0 & 1 & 1 & 0 & 0 & 0 & 4 & 1 & 5 & None \\
\hline $\begin{array}{r}\text { Kahle et al., } \\
2008 \text { [31] }\end{array}$ & 1 & 0 & 1 & 0 & 1 & 1 & 0 & 1 & 1 & 1 & 0 & 0 & 1 & 6 & 2 & 8 & B \\
\hline $\begin{array}{l}\text { Hafner \& Smith, } \\
2009 \text { [21] }\end{array}$ & 1 & 1 & 1 & 0 & 1 & 1 & 0 & 1 & 1 & 1 & 0 & 0 & 1 & 7 & 2 & 9 & B \\
\hline $\begin{array}{c}\text { Theeven et al., } \\
2011 \text { [98] }\end{array}$ & 1 & 1 & 1 & 1 & 1 & 1 & 0 & 0 & 1 & 0 & 1 & 0 & 1 & 7 & 2 & 9 & C \\
\hline $\begin{array}{l}\text { Burnfield et al., } \\
2012 \text { [100] }\end{array}$ & 1 & 0 & 1 & 0 & 1 & 1 & 0 & 1 & 1 & 1 & 0 & 0 & 1 & 6 & 2 & 8 & B \\
\hline $\begin{array}{c}\text { Theeven et al., } \\
2012 \text { [99] }\end{array}$ & 1 & 1 & 1 & 1 & 1 & 1 & 0 & 0 & 1 & 0 & 1 & 0 & 1 & 7 & 2 & 9 & C \\
\hline $\begin{array}{l}\text { Eberly et al., } \\
2014 \text { [101] }\end{array}$ & 1 & 1 & 1 & 0 & 1 & 1 & 0 & 1 & 1 & 1 & 0 & 0 & 1 & 7 & 2 & 9 & B \\
\hline
\end{tabular}


JRRD, Volume 51, Number 10, 2014

Table 3.

Patient demographics and non-microprocessor-controlled prosthetic knees used as controls in clinical trials included and reviewed.

\begin{tabular}{|c|c|c|c|c|}
\hline \multirow[b]{2}{*}{ Demographic } & \multicolumn{4}{|c|}{ Study } \\
\hline & Kahle et al., 2008 [31] & $\begin{array}{l}\text { Hafner \& Smith, } 2009 \\
\text { [21] }\end{array}$ & $\begin{array}{l}\text { Theeven et al., 2011/ } \\
2012 \text { [98-99] }\end{array}$ & $\begin{array}{c}\text { Burnfield et al., } 2012 \\
\text { [100] and Eberly et al., } \\
2014 \text { [101] }\end{array}$ \\
\hline Total $(n)$ & 19 & 17 & 30 & 10 \\
\hline MFCL-2 (n) & 9 & 8 & $30^{*}$ & 10 \\
\hline \multicolumn{5}{|l|}{ Etiology } \\
\hline $\begin{array}{l}\text { Dysvascular PVD and/ } \\
\text { or Diabetes }\end{array}$ & 7 & 1 & 6 & 6 \\
\hline Trauma & 1 & 5 & 23 & 2 \\
\hline Other & 1 & 2 & 1 & 2 \\
\hline \multicolumn{5}{|l|}{ Sex } \\
\hline Male & Not Reported & 6 & 22 & 5 \\
\hline Female & Not Reported & 2 & 8 & 5 \\
\hline Age, yr (mean \pm SD) & $67.1 \pm 11.8$ & $57.1 \pm 15.4$ & $59.1 \pm 13.0$ & $62.0 \pm 11.3$ \\
\hline Intervention & C-Leg & C-Leg & $\begin{array}{l}\text { C-Leg and C-Leg } \\
\text { Compact }\end{array}$ & C-Leg Compact \\
\hline \multicolumn{5}{|l|}{ Control Knee } \\
\hline Locked & - & - & 3 & - \\
\hline Weight-Activated Brake & 4 & - & 5 & 4 \\
\hline Polycentric & 4 & 6 & 17 & 5 \\
\hline Hydraulic & 1 & 2 & 5 & 1 \\
\hline $\begin{array}{l}\text { Accommodation Time to } \\
\text { Intervention }\end{array}$ & $90 \mathrm{~d}$ & 1-33 wk (mean: 13.5 wk) & $1 \mathrm{wk}$ & $3 \mathrm{mo}$ \\
\hline
\end{tabular}

of prosthesis use (Table 4) [21,31,100]. All three studies had a moderate methodological quality. Because safety is of utmost clinical importance to lower-functioning individuals with a TFA and the patient number of the studies reviewed in this area was rather small $(\leq 10)$, we did not only analyze significant differences but also statistical trends with $0.05 \leq p<0.1$ because they may have only been insignificant because the studies were statistically underpowered.

Kahle et al. [31] allowed for a post hoc analysis of the number of stumbles and falls that demonstrated a statistically significant reduction of 80 percent in falls that was confirmed by Hafner and Smith [21]. The latter also found a significant decrease in the frequency of stumbles and uncontrolled falls with the C-Leg as well as a statistical trend to reduce frustration with falls and improved confidence while walking. The number of stumbles, embarrassment with falls, and frequency and number of semicontrolled falls did not differ between the knee joint conditions. Burnfield et al. reported a significant improvement in the performance-based time to complete the TUG and in perceived balance in 16 ADLs as measured by the ABC with the MPK [100].

In summary, out of the 13 validated safety-related outcome measures assessed in the three studies, not a single outcome measure showed a significant benefit or statistical trend in favor of the NMPKs. Four outcome measures (39\%) showed no difference between the knee joint conditions. Six outcome measures (46\%), including the only performance-based one, demonstrated a significant improvement, and two outcome measures (15\%) showed a statistical trend toward improvement when using a C-Leg or C-Leg Compact. A significant reduction in falls and the risk of falling as well as a significant improvement in balance were obtained in subjects across the whole MFCL-2 mobility spectrum studied, from fastest possible walking velocities between 1.8 and $3.3 \mathrm{~km} / \mathrm{h}$ 
Table 4.

Safety outcomes. Due to low patient number of studies, safety outcomes with statistical trend toward significance $(p<0.10)$ were also analyzed.

\begin{tabular}{|c|c|c|c|}
\hline \multirow[b]{2}{*}{ Outcome } & \multicolumn{3}{|c|}{ Study } \\
\hline & Kahle et al., 2008 [31] & $\begin{array}{l}\text { Hafner \& Smith, } 2009 \\
\text { [21] }\end{array}$ & $\begin{array}{l}\text { Burnfield et al., } 2012 \\
{[100]}\end{array}$ \\
\hline Methodological Quality & $\mathrm{B}$ & $\mathrm{B}$ & $\mathrm{B}$ \\
\hline $\begin{array}{l}\text { Fastest Walking Speed on } \\
\text { NMPK Prosthesis }\end{array}$ & $\begin{array}{l}75 \mathrm{~m} \text { walk test: } 2.68 \pm \\
0.68 \mathrm{~km} / \mathrm{h}(0.75 \pm 0.19 \mathrm{~m} / \mathrm{s})\end{array}$ & Not reported & $\begin{array}{l}\text { Gait analysis: } 2.48 \pm \\
0.79 \mathrm{~km} / \mathrm{h}(0.69 \pm 0.22 \mathrm{~m} / \mathrm{s})\end{array}$ \\
\hline Measurement Method & Interview & Questionnaire (VAS) & $\begin{array}{l}\text { Clinical test, questionnaire } \\
\text { (VAS) }\end{array}$ \\
\hline $\begin{array}{l}\text { Results with Statistical Sig- } \\
\text { nificance }(p<0.05) \text { in Favor } \\
\text { of MPK }\end{array}$ & $\begin{array}{l}\text { Number of falls decreased } \\
81 \% \text { from } 2.1 \pm 1.5 \text { to } 0.4 \pm \\
0.7(p=0.05)^{*}\end{array}$ & $\begin{array}{l}\text { Frequency of stumbles } \\
\text { decreased } 15.8 \%(p=0.05) \text {; } \\
\text { Number of uncontrolled } \\
\text { falls decreased } 80 \%(p= \\
0.01) \text {; Frequency of uncon- } \\
\text { trolled falls decreased } 4.5 \% \\
(p=0.01)\end{array}$ & $\begin{array}{l}\text { TUG decreased } 28 \% \text { from } \\
24.5 \text { to } 17.7 \text { s }(p=0.02) \text {; } \\
\text { ABC improved } 26 \% \text { from } \\
60.1 \text { to } 75.7(p=0.001)\end{array}$ \\
\hline $\begin{array}{l}\text { Results with Statistical } \\
\text { Trend }(0.05 \leq p<0.10) \text { in } \\
\text { Favor of MPK }\end{array}$ & None & $\begin{array}{l}\text { Confidence while walking } \\
\text { improved } 12 \%(p=0.08) ; \\
\text { Frustration with falls } \\
\text { decreased } 23.4 \%(p=0.06)\end{array}$ & None \\
\hline $\begin{array}{l}\text { Results Showing No Statis- } \\
\text { tical Difference Between } \\
\text { MPK and NMPK }\end{array}$ & Number of stumbles & $\begin{array}{l}\text { Embarrassment with falls; } \\
\text { Number of stumbles; Fre- } \\
\text { quency of semicontrolled } \\
\text { falls; Number of semicon- } \\
\text { trolled falls }\end{array}$ & None \\
\hline $\begin{array}{l}\text { Results with Statistical } \\
\text { Trend }(0.05 \leq p<0.10) \text { in } \\
\text { Favor of NMPK }\end{array}$ & None & None & None \\
\hline
\end{tabular}

${ }^{*}$ Analyzed from individual data of MFCL-2 subjects reported in article, Wilcoxon signed rank test.

ABC = Activity-specific Balance Confidence Scale, MFCL = Medicare Functional Classification Level, MPK = microprocessor-controlled knee, NMPK $=$ nonmicroprocessor-controlled prosthetic knee, PEQ = Prosthesis Evaluation Questionnaire, TUG = Timed "Up and Go" test, VAS = visual analog scale.

$(0.50-0.92 \mathrm{~m} / \mathrm{s})$ to subjects presenting AMP values between 34 and 41 on their NMPK.

\section{Performance-Based Function and Mobility Outcomes}

Performance-based function and mobility outcomes were reported by all six articles with a total of 57 subjects with MFCL-2 mobility grade (Table 5) [21,31,98-101]. Four articles were ranked moderate and two ranked low in methodological quality. The studies analyzed have reported on a variety of different mobility outcomes with the synthesis of results suggesting that persons with unilateral TFA and MFCL-2 mobility grade are able to walk about 14 to 25 percent faster on level ground [31,101], around 20 percent quicker on uneven surfaces [21,31], and almost 30 percent faster when descending a slope or hill [21,100] when using an MPK than with an NMPK. Two studies each consistently demonstrated an improvement in stair descent [21,31] and slope descent [21,100] qualities when using an MPK. Hafner and Smith also saw an increase in divided attention walking speed on the CLeg but no difference in the accuracy of the divided attention tasks between the knee conditions [21]. In a reevaluation of the patients' mobility grade after accommodation to the C-Leg, two studies found that 44 [31] or 
JRRD, Volume 51, Number 10, 2014

Table 5.

Function and mobility outcomes. Note that AS1 = standing activities requiring adequate balance, AS2 = activities requiring sitting down and standing up, and AS3 = ambulation activities heavily depending on patient's prosthesis-related skills.

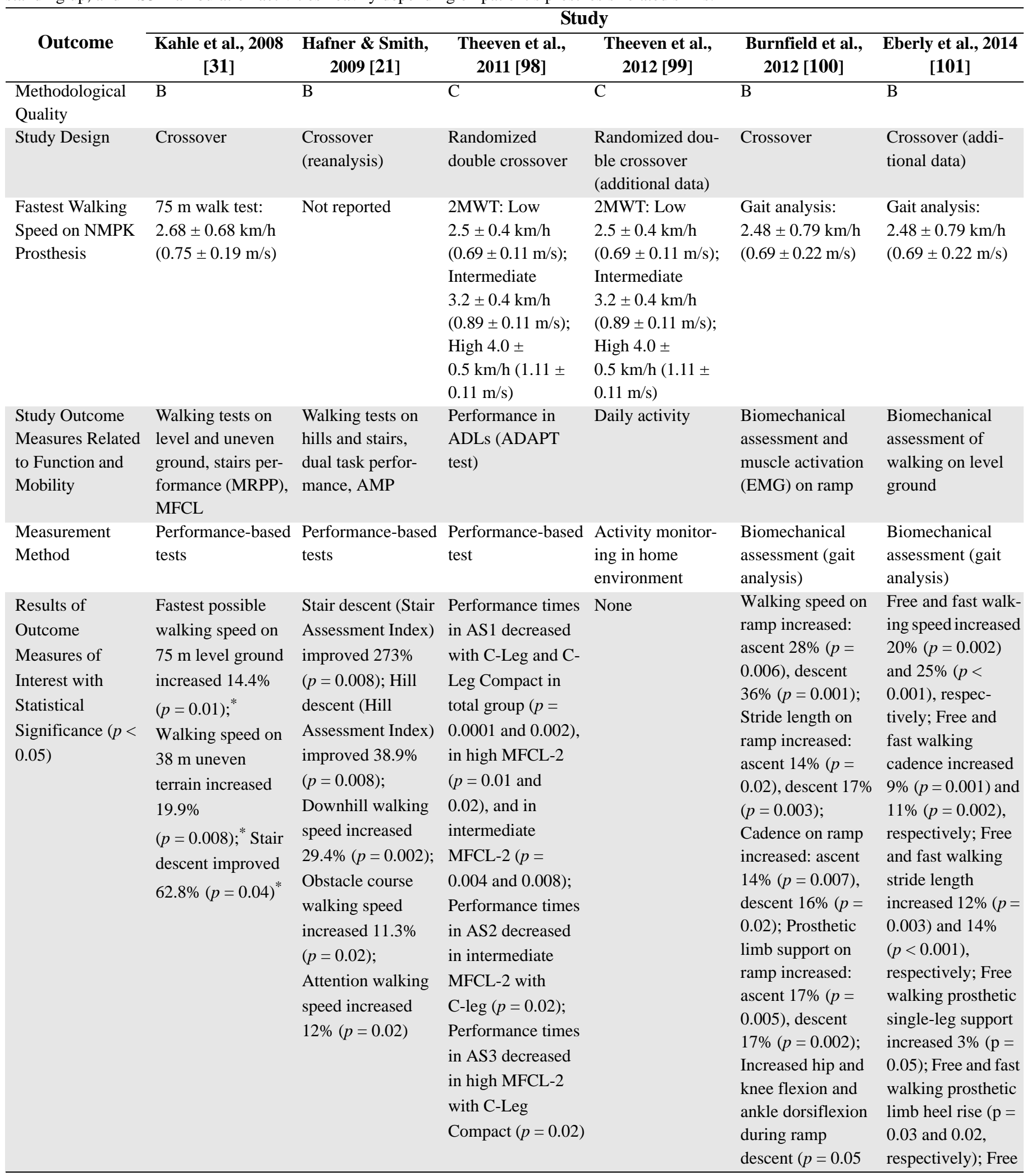


Table 5. (cont)

Function and mobility outcomes. Note that AS1 = standing activities requiring adequate balance, AS2 = activities requiring sitting down and standing up, and AS3 = ambulation activities heavily depending on patient's prosthesis-related skills.

\begin{tabular}{|c|c|c|c|c|c|c|}
\hline \multirow[b]{2}{*}{ Outcome } & \multicolumn{6}{|c|}{ Study } \\
\hline & $\begin{array}{c}\text { Kahle et al., } 2008 \\
{[31]}\end{array}$ & $\begin{array}{c}\text { Hafner \& Smith, } \\
2009[21]\end{array}$ & $\begin{array}{c}\text { Theeven et al., } \\
2011 \text { [98] }\end{array}$ & $\begin{array}{c}\text { Theeven et al., } \\
2012 \text { [99] }\end{array}$ & $\begin{array}{c}\text { Burnfield et al., } \\
2012[100]\end{array}$ & $\begin{array}{c}\text { Eberly et al., } 2014 \\
{[101]}\end{array}$ \\
\hline & & & & & $\begin{array}{l}\text { each); Earlier } \\
\text { prosthetic limb } \\
\text { heel-off during } \\
\text { ramp descent: } 21 \% \\
(p=0.01)\end{array}$ & $\begin{array}{l}\text { and fast walking } \\
\text { peak hip and thigh } \\
\text { extension angles } \\
\text { during stance ( } p= \\
0.005 \text { each); Free } \\
\text { and fast walking } \\
\text { peak ankle stance } \\
\text { moment ( } p=0.001 \\
\text { and } 0.008 \text {, } \\
\text { respectively); Fast } \\
\text { walking peak knee } \\
\text { loading moment } \\
\text { ( } p=0.05) ; \text { Free and } \\
\text { fast walking peak } \\
\text { knee terminal } \\
\text { stance moment } \\
\text { ( } p=0.04 \text { and } 0.03 \text {, } \\
\text { respectively); Fast } \\
\text { walking peak hip } \\
\text { stance moment } \\
\text { ( } p=0.02) ; \text { Fast } \\
\text { walking preswing } \\
\text { ankle power } \\
\text { generation ( } p= \\
0.04) ; \text { Fast walking } \\
\text { peak hip loading } \\
\text { response generation } \\
\text { ( } p=0.05 \text { ); Free and } \\
\text { fast walking intact } \\
\text { limb tibialis anterior } \\
\text { muscle activity ( } p= \\
0.002 \text { and } 0.003 \text {, } \\
\text { respectively) and } \\
\text { prosthetic limb } \\
\text { gluteus maximus } \\
\text { activity ( } p=0.02 \\
\text { and } 0.02 \text {, } \\
\text { respectively) }\end{array}$ \\
\hline $\begin{array}{l}\text { Results Showing } \\
\text { No Statistical } \\
\text { Difference } \\
\text { Between MPK } \\
\text { and NMPK }\end{array}$ & $\begin{array}{l}\text { Self-selected } \\
\text { walking speed on } \\
75 \text { m level } \\
\text { ground; }{ }^{*} \text { Fastest } \\
\text { possible walking } \\
\text { speed on } 6 \text { m level } \\
\text { ground }^{*}\end{array}$ & $\begin{array}{l}\text { AMP; }{ }^{*} \text { Accuracy } \\
\text { of divided attention } \\
\text { task while walking }\end{array}$ & $\begin{array}{l}\text { Performance time in } \\
\text { AS1 activities in } \\
\text { low MFCL-2 with } \\
\text { both MPKs; } \\
\text { Performance time in } \\
\text { AS2 activities in } \\
\text { total group and all } \\
\text { subgroups with }\end{array}$ & $\begin{array}{l}\text { Up-time per day; } \\
\text { Active time per } \\
\text { day; Activity } \\
\text { (counts and bouts) } \\
\text { per day in total, } \\
\text { high, and low } \\
\text { subgroup with } \\
\text { either MPK and in }\end{array}$ & $\begin{array}{l}\text { Prosthetic limb } \\
\text { stance duration in } \\
\text { percent of GC } \\
\text { during ascent and } \\
\text { descent; Prosthetic } \\
\text { limb heel-off in } \\
\text { percent of GC } \\
\text { during ascent; }\end{array}$ & $\begin{array}{l}\text { Fast walking } \\
\text { prosthetic limb } \\
\text { single-leg support; } \\
\text { Free and fast } \\
\text { walking peak knee } \\
\text { and ankle angles; } \\
\text { Free walking peak } \\
\text { hip stance moment; }\end{array}$ \\
\hline
\end{tabular}


Table 5. (cont)

Function and mobility outcomes. Note that AS1 = standing activities requiring adequate balance, AS2 = activities requiring sitting down and standing up, and AS3 = ambulation activities heavily depending on patient's prosthesis-related skills.

\begin{tabular}{|c|c|c|c|c|c|c|}
\hline \multirow[b]{2}{*}{ Outcome } & \multicolumn{6}{|c|}{ Study } \\
\hline & $\begin{array}{c}\text { Kahle et al., } 2008 \\
{[31]}\end{array}$ & $\begin{array}{c}\text { Hafner \& Smith, } \\
2009[21]\end{array}$ & $\begin{array}{c}\text { Theeven et al., } \\
2011 \text { [98] }\end{array}$ & $\begin{array}{c}\text { Theeven et al., } \\
2012 \text { [99] }\end{array}$ & $\begin{array}{c}\text { Burnfield et al., } \\
2012[100]\end{array}$ & $\begin{array}{c}\text { Eberly et al., } 2014 \\
{[101]}\end{array}$ \\
\hline $\begin{array}{l}\text { Results with } \\
\text { Statistical } \\
\text { Significance ( } p< \\
0.05 \text { ) in favor of } \\
\text { NMPK }\end{array}$ & None & None & None & $\begin{array}{l}\text { Activity count per } \\
\text { day in intermediate } \\
\text { group with C-leg } \\
(p=0.02)\end{array}$ & None & None \\
\hline
\end{tabular}

50 [21] percent, respectively, of the MFCL-2 individuals had improved their mobility grade to MFCL-3. Theeven et al. reported significant improvements in performance times for different categories of ADLs in the total group and/or the intermediate and/or high subgroups of MFCL-2 individuals when using the C-Leg and/or the C-Leg Compact [98]. Both the C-Leg and C-Leg Compact significantly improved performance in ADLs requiring adequate balance in the total group and the intermediate and high subgroups. In addition, the C-Leg Compact significantly improved performance in ADLs requiring sitting down and standing up in the intermediate subgroup, whereas the C-Leg significantly improved performance in ADLs heavily dependent on the patient's prosthesis-related skills in the high subgroup. In a later publication, no differences between up-time, active time, and activity during the day were seen when using the different prosthetic knees, with the exception of the intermediate subgroup demonstrating a reduced activity count after 1 wk of accommodation to the C-Leg [99]. 
In summary, out of a total of 51 performance-based outcome measures and 40 biomechanical gait parameters that are related to function and mobility subjected to statistical analysis, only the activity count per day in the intermediate subgroup of Theeven et al. showed a significant effect in favor of the NMPK as compared with the C-Leg [99]. In 23 outcome measures (45\%) and 22 biomechanical gait parameters (55\%), no differences were found between the prosthetic knee conditions. For 28 outcome measures (55\%) and 18 biomechanical gait parameters (45\%), a significant improvement was demonstrated when using an MPK, enabling patients to better and/or faster execute indoor ADLs as well as activities of community ambulation typical for MFCL-3 mobility grade such as medium-distance level, uneven terrain, slope, and hill walking as well as stair negotiation. However, an interesting relationship between the fastest possible walking speed on the NMPK and these improvements was seen. Improvements in abilities necessary for community ambulation were demonstrated in individuals across all subgroups of the MFCL-2 mobility grade range, represented by slow to medium maximum walking velocities between 1.8 and $3.3 \mathrm{~km} / \mathrm{h}(0.50-0.92 \mathrm{~m} / \mathrm{s})$ and high AMP values between 34 and 41. In contrast, improvements in indoor ADLs were only seen in individuals walking with medium to high maximum velocities between 2.8 and $4.5 \mathrm{~km} / \mathrm{h}(0.78-1.25 \mathrm{~m} / \mathrm{s})$.

\section{Perceived Function, Satisfaction, and Prosthesis Preference}

Results on perceived function and satisfaction were reported by five articles with a total of 57 subjects with MFCL-2 mobility grade (Table 6) [21,31,98-100]. Three of these articles $[21,31,100]$ had a moderate methodological quality and two [98-99] had a low methodological quality. Hafner and Smith reported a significant improvement of the perceived ability for multitasking while walking with the C-Leg [21]. Burnfield et al. found a significant improvement in the PEQ Mobility scale, but not in the Houghton Scale, when using the C-Leg Compact [100]. Theeven et al. found a significant reduction in perceived difficulty to perform ADLs requiring sitting down and standing up and those heavily dependent on the patient's prosthesis-related skills in the total MFCL-2 study group with the C-Leg but not in the subgroups and not when using the C-Leg Compact [98]. In a later article, the same research group reported significant improvements in self-reported ambulation, utility, residual-limb health, and satisfaction with walking in the total group and/or certain subgroups of the same MFCL2 sample when using the C-Leg and/or C-Leg Compact [99]. Satisfaction with the prosthesis improved significantly in the total group with the C-Leg (Table 6).

In summary, out of the 96 self-reported outcome measures not a single one demonstrated superiority of the NMPKs. For the majority of 74 perceived outcome measures $(77 \%)$, no significant differences were found between the prosthetic knee interventions. Use of an MPK resulted in significant improvements in 22 selfreported outcome measures (23\%). These were mainly demonstrated for subjects walking at medium to higher velocities between 2.8 and $4.5 \mathrm{~km} / \mathrm{h}(0.78-1.25 \mathrm{~m} / \mathrm{s})$.

In their earlier article, Theeven et al. reported that 70 percent of the MFCL-2 individuals subjectively preferred the C-Leg, 23 percent preferred the C-Leg Compact, and only 7 percent preferred their previous NMPK [98]. These results are consistent with the findings of Kahle et al., who found that 90 percent of the MFCL-2 subjects in their study preferred the C-Leg [31].

In addition, it is noteworthy that neither study reported any adverse events in association with the use of the C-Leg or C-Leg Compact.

\section{DISCUSSION}

We conducted a systematic review of the literature in order to analyze whether or not individuals with a unilateral TFA and MFCL-2 mobility grade may benefit from using MPKs, as has been demonstrated for higher-functioning MFCL-3 individuals [21,23-36]. We were able to identify four studies with six articles that had investigated the effects of MPK use in subjects with a unilateral TFA and MFCL-2 mobility grade and sufficient methodological quality. The moderate to low methodological quality found for the studies complies with the findings of earlier systematic reviews of MPK intervention studies $[23,36,96]$. Consider, however, that there are serious challenges to prosthetic research, such as limited patient numbers and limited access of research institutions to patients, great functional and prognostic heterogeneity of patients, and practical impossibility of blinding, that result in a comparatively limited methodological quality of prosthetic studies in general $[96,103]$. Nevertheless, the quality of many clinical studies with MP-controlled components is the highest in the field of prosthetics. 
JRRD, Volume 51, Number 10, 2014

Table 6.

Perceived function and mobility, satisfaction, and preference outcomes. Note that AS1 = standing activities requiring adequate balance, AS2 = activities requiring sitting down and standing up, and AS3 = ambulation activities heavily depending on patient's prosthesis-related skills.

\begin{tabular}{|c|c|c|c|c|c|}
\hline \multirow[b]{2}{*}{ Outcome } & \multicolumn{5}{|c|}{ Study } \\
\hline & Kahle et al., 2008 [31] & $\begin{array}{c}\text { Hafner \& Smith, } 2009 \\
{[21]}\end{array}$ & $\begin{array}{c}\text { Theeven et al., } 2011 \\
\text { [98] }\end{array}$ & $\begin{array}{c}\text { Burnfield et al., } 2012 \\
\text { [100] }\end{array}$ & $\begin{array}{c}\text { Theeven et al., } 2012 \\
\text { [99] }\end{array}$ \\
\hline $\begin{array}{l}\text { Methodological } \\
\text { Quality }\end{array}$ & B & B & $\mathrm{C}$ & B & $\mathrm{C}$ \\
\hline Study Design & Crossover & $\begin{array}{l}\text { Crossover } \\
\text { (reanalysis) }\end{array}$ & $\begin{array}{l}\text { Randomized double } \\
\text { crossover }\end{array}$ & Crossover & $\begin{array}{l}\text { Randomized double } \\
\text { crossover (additional } \\
\text { data) }\end{array}$ \\
\hline Measurement Method & Interview & Questionnaire (VAS) & $\begin{array}{l}\text { Questionnaire (VAS), } \\
\text { interview }\end{array}$ & Questionnaire (VAS) & Questionnaire \\
\hline $\begin{array}{l}\text { Results with } \\
\text { Statistical } \\
\text { Significance ( } p< \\
0.05) \text { in Favor of } \\
\text { MPK }\end{array}$ & $\begin{array}{l}\text { No statistical } \\
\text { comparisons }\end{array}$ & $\begin{array}{l}\text { Multitasking while } \\
\text { walking improved } \\
21.2 \%(p=0.04)\end{array}$ & $\begin{array}{l}\text { Perceived difficulty } \\
\text { of AS2 and AS3 } \\
\text { activities decreased } \\
\text { in total group with C- } \\
\text { Leg ( } p=0.02 \text { and } \\
0.008)\end{array}$ & $\begin{array}{l}\text { PEQ Mobility score } \\
\text { improved 25\% ( } p= \\
0.04)\end{array}$ & $\begin{array}{l}\text { PEQ Ambulation } \\
\text { improved with C-Leg } \\
\text { in total group 11.5\% } \\
\text { ( } p=0.01) \text { and in inter- } \\
\text { mediate MFCL-2 } \\
\text { group 11.3\% ( } p= \\
\text { 0.009); PEQ Utility } \\
\text { improved with C-Leg } \\
\text { in total group 12\% } \\
\text { ( } p=0.006) \text {, in high } \\
\text { group 12.9\% ( } p= \\
0.04) \text {, and in interme- } \\
\text { diate group } 17.1 \% \text { ( } p= \\
0.02) \text { and with C-Leg } \\
\text { Compact in total } \\
\text { group 11.9\% ( } p= \\
\text { 0.02) and in high } \\
\text { group 15.5\% ( } p= \\
0.02) \text {; PEQ Residual } \\
\text { Limb Health } \\
\text { improved with C-Leg } \\
\text { and C-Leg Compact } \\
\text { in total group } 16.0 \% \\
\text { and 22.0\% ( } p=0.003 \\
\text { and 0.002) and in high } \\
\text { MFCL-2 group27.0\% } \\
\text { and 37.3\% ( } p=0.01 \\
\text { and 0.006); Satisfac- } \\
\text { tion with walking }\end{array}$ \\
\hline
\end{tabular}


Table 6. (cont)

Perceived function and mobility, satisfaction, and preference outcomes. Note that AS1 = standing activities requiring adequate balance, AS2 = activities requiring sitting down and standing up, and AS3 = ambulation activities heavily depending on patient's prosthesis-related skills.

\begin{tabular}{|c|c|c|c|c|c|}
\hline \multirow[b]{2}{*}{ Outcome } & \multicolumn{5}{|c|}{ Study } \\
\hline & Kahle et al., 2008 [31] & $\begin{array}{c}\text { Hafner \& Smith, } 2009 \\
{[21]}\end{array}$ & $\begin{array}{c}\text { Theeven et al., } 2011 \\
{[98]}\end{array}$ & $\begin{array}{c}\text { Burnfield et al., } 2012 \\
{[100]}\end{array}$ & $\begin{array}{c}\text { Theeven et al., } 2012 \\
\text { [99] }\end{array}$ \\
\hline & & & & & $\begin{array}{l}\text { improved with C- } \\
\text { Leg in total group } \\
23.7 \%(p=0.003) \\
\text { and in high MFCL-2 } \\
15.0 \%(p=0.04) \\
\text { with both C-Leg } \\
\text { 49.8\% ( } p=0.007) \\
\text { and C-Leg Compact } \\
\text { 36.5\% ( } p=0.05) \text { in } \\
\text { intermediate MFCL- } \\
2 \text {; Satisfaction with } \\
\text { prosthesis improved } \\
\text { with C-Leg 15.2\% } \\
\text { in total group ( } p= \\
0.05 \text { ) }\end{array}$ \\
\hline $\begin{array}{l}\text { Results Showing } \\
\text { No Statistical } \\
\text { Difference Between } \\
\text { MPK and NMPK }\end{array}$ & $\begin{array}{l}\text { No statistical } \\
\text { comparisons }\end{array}$ & $\begin{array}{l}\text { PEQ Satisfaction; } \\
\text { PEQ Ambulation; } \\
\text { PEQ Appearance; } \\
\text { PEQ Frustration; } \\
\text { PEQ Perceived } \\
\text { Response; PEQ } \\
\text { Residual Limb } \\
\text { Health; PEQ Social } \\
\text { Burden; PEQ Utility; } \\
\text { PEQ Well-being; } \\
\text { Mental Energy } \\
\text { Expenditure; } \\
\text { Difficulty with } \\
\text { concentration; } \\
\text { Activity avoidance }\end{array}$ & $\begin{array}{l}\text { Perceived difficulty } \\
\text { with AS1 in total } \\
\text { group and all } \\
\text { subgroups with both } \\
\text { MPKs; Perceived } \\
\text { difficulty with AS2 } \\
\text { and AS3 activities in } \\
\text { total group with C- } \\
\text { Leg Compact and } \\
\text { with both MPKs in } 3 \\
\text { MFCL-2 subgroups }\end{array}$ & Houghton Scale & $\begin{array}{l}\text { PEQ Ambulation in } \\
\text { high and low } \\
\text { subgroup with C- } \\
\text { Leg and total group } \\
\text { and all subgroups } \\
\text { with C-Leg } \\
\text { Compact; PEQ } \\
\text { Appearance in total } \\
\text { group and all } \\
\text { subgroups with both } \\
\text { MPKs; PEQ } \\
\text { Residual Limb } \\
\text { Health in low and } \\
\text { intermediate } \\
\text { subgroup with both } \\
\text { MPKs; PEQ Sounds } \\
\text { in all groups with } \\
\text { both MPKs; PEQ } \\
\text { Utility in low } \\
\text { subgroup for C-Leg } \\
\text { and in low and } \\
\text { intermediate } \\
\text { subgroup for C-Leg } \\
\text { Compact; PEQ } \\
\text { Well-being in all } \\
\text { groups with both } \\
\text { MPKs; Satisfaction } \\
\text { with prosthesis in all } \\
\text { subgroups with C- } \\
\text { Leg and all groups } \\
\text { with C-Leg Compact; }\end{array}$ \\
\hline
\end{tabular}


Table 6. (cont)

Perceived function and mobility, satisfaction, and preference outcomes. Note that AS1 = standing activities requiring adequate balance, AS2 = activities requiring sitting down and standing up, and AS3 = ambulation activities heavily depending on patient's prosthesis-related skills.

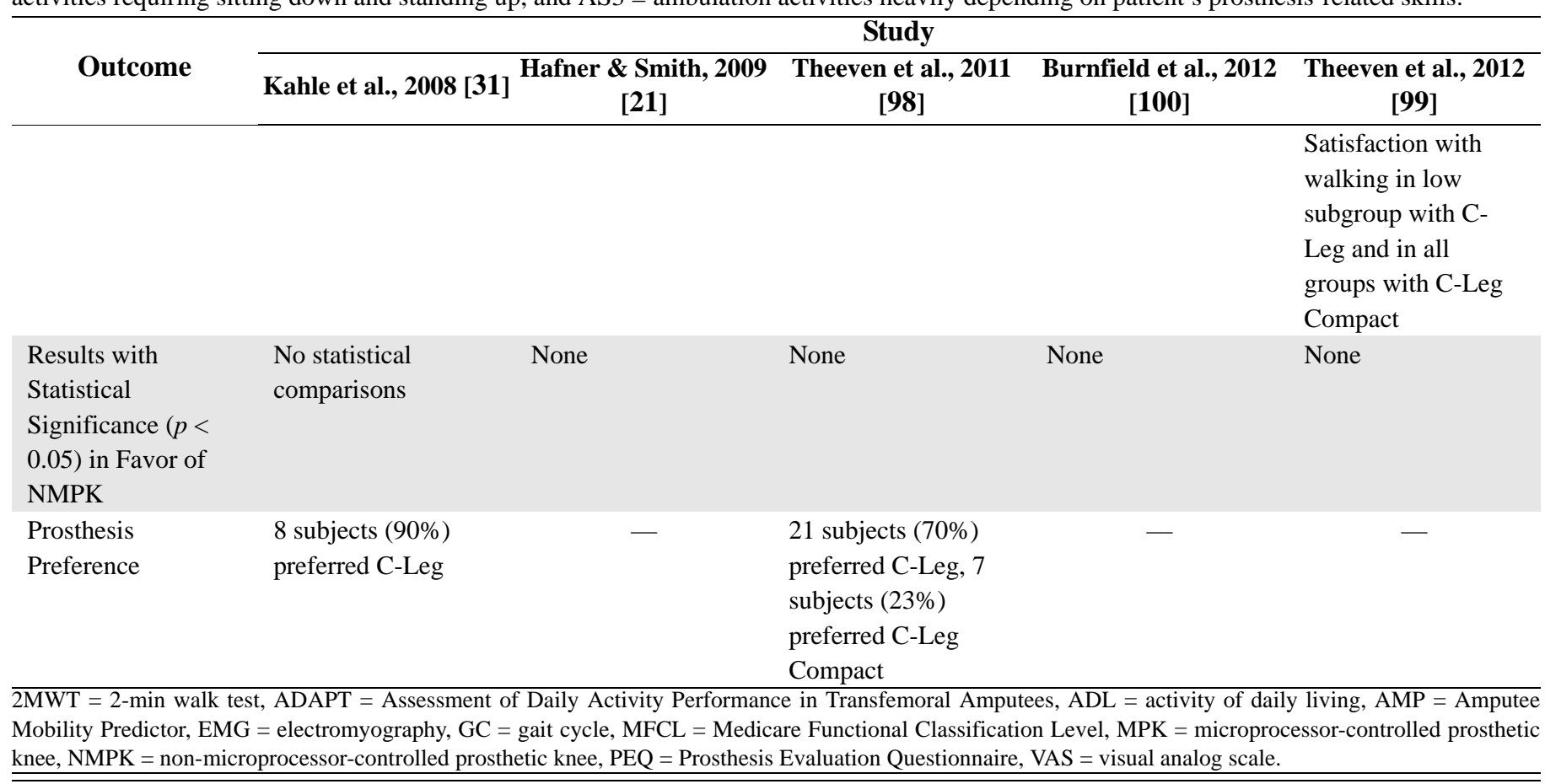

\section{Safety}

Objective and perceived safety is the foundation of proficient prosthesis use and improvement in function and mobility [8,44-50,104]. The two studies that investigated the MP stance and swing controlled C-Leg demonstrated a significant reduction in the self-reported number and frequency of uncontrolled falls than with the use of the NMPKs $[21,31]$. The only study that investigated the MP stance controlled C-Leg Compact found a significant reduction in the completion time of the performancebased TUG [57-61] that was almost twice as large as the minimal detectable change (MDC) as reported by Resnik and Borgia [105]. The TUG even fell below the cutoff value of $19 \mathrm{~s}$ as reported by Dite et al. to indicate a risk of multiple falls in people with transtibial amputation [62]. This finding was accompanied by a significant improvement in self-reported balance as measured by the ABC exceeding the validated score of 67 , indicating a low risk of falling $[6-7,66]$. In summary, the best validated performance-based safety outcome measure and those selfreported measures indicating the most dangerous adverse events of prosthesis use consistently demonstrated a significant gain in safety when using an MPK. In contrast, the measures that found no difference between the pros- thetic knees are all indicators of events that are certainly unpleasant, such as stumbles and semicontrolled falls, but involve considerably lesser risks of serious consequences. Two of the studies found improvements in safety in subjects capable of walking between 1.8 and $3.3 \mathrm{~km} / \mathrm{h}$ on their NMPK prosthesis $[31,100]$. The third article did not report walking speeds, but the AMP values suggest that the patients belonged to the medium- to high-functioning segment of the MFCL-2 population [21]. Thus, it can be concluded that the two hydraulic MPKs studied may improve the safety of prosthesis use in individuals with a unilateral TFA and MFCL-2 mobility grade to the same extent as they do in subjects with a higher mobility grade level $[23,36]$.

The significant gain in safety can be explained by the difference in technology between the MP default stance control and the non-MP default swing control knees that are usually prescribed for MFCL-2 subjects, namely weight-activated "safety" brake knees and 4-bar or multiaxial polycentric knees. In brake knees, stance control and stability is activated by the combination of full knee extension and weight loading. In polycentric knees, stance stability is achieved by projection of the instantaneous center of rotation (ICR) behind the vector of the 
vertical ground reaction force (GRF) at full knee extension. If not fully extended at heel strike, both brake and polycentric knees may fail to provide knee stability due to lever moments exceeding the braking capacity (brake knees) or shift of the ICR close to or even in front of the GRF (polycentric knees) resulting in a knee flexion moment that immediately voids knee stability. Full knee extension at loading response can be achieved by walking straight on level ground with more or less fixed velocity, cadence, and stride length as is postulated for MFCL-2 individuals. However, many ADLs and community ambulation require locomotion in confined spaces with turns, stepping in different directions, variation of step length, negotiation of barriers and obstacles, and movements of the upper body that may change the position of the center of mass and the resulting GRF, which may prevent the prosthetic knee from reaching full extension [25]. Designed as default swing knees, brake and polycentric knees will inevitably collapse when loaded in such situations [16-22,106-108], thus exposing the patient to a substantial risk of falling. The very limited safety of weight-activated brake knees has been demonstrated in a clinical trial with elderly persons with a dysvascular above-knee amputation [104]. Although accommodated to the brake knee, the patients preferred a locked knee for safety reasons [104].

In contrast, the default setting of the two MPKs studied is to control stance stability unless they are explicitly switched into swing control. But even when in the swing mode, the two MPKs provide high flexion resistance for stumble recovery during the swing extension movement that is able to prevent knee collapse even if the prosthesis is fully loaded [27,35]. Unlike in the typical MFCL-2 knee joints, turns, changes in walking direction, movements of the upper body, stepping onto obstacles, walking on ramps, walking on stairs, and even stumbles do not affect the stance safety of the C-Leg or C-Leg Compact $[24-25,27,35]$.

With the safety limitations described previously, the prosthetic knees typically prescribed for MFCL-2 individuals may even contribute to activity avoidance, increased dependency, and limited community ambulation. Because the C-Leg and C-Leg Compact have been demonstrated to reduce uncontrolled falls, to lower the risk of falling, and to improve balance, they may create a safe foundation for increasing community ambulation and independence in individuals with a TFA and MFCL-2 mobility grade.

\section{Performance-Based Function and Mobility}

All six articles consistently reported that, when using an MPK, limited community ambulators may significantly improve their abilities to perform activities of community ambulation such as negotiating uneven terrain and environmental obstacles [21,31], ramps [100], hills [21], and stairs [21,31] and multitasking while walking [21]. The higher-functioning MFCL-2 subgroups may also improve the ability to perform many indoor ADLs [98]. The reduction in the activity count seen in the intermediate subgroup of Theeven et al. [99] when using an MPK might possibly be explained by the increase in stride length as demonstrated in one of the other articles [101], resulting simply in fewer steps required to ambulate the same distance. The significant improvements in 55 percent of all performance-based outcome measures assessed indicate that the two hydraulic MPKs studied may enable limited community ambulators to perform activities that, by definition, are typical for unlimited community ambulators with MFCL-3 mobility grade. This is further supported by the fact that two articles found that 44 to 50 percent of MFCL-2 subjects were able to improve their overall functional level to MFCL-3 when using a C-Leg [21,31]. However, these findings must be interpreted with caution, because the definition of the MFCL is very general and grants much room for subjective interpretation by the assessor, especially when speculating about the functional "potential" of the patient (Table 1). To date, no approved tests exist to objectify the assignment of a patient to a certain functional level. The AMP has been proposed to address this issue, but the currently recommended cutoff values to distinguish the functional levels have not yet been validated [69]. Nevertheless, one or more performance-based tests to objectify the functional classification or even a completely new, validated, and unambiguously quantifiable functional classification of patients that ideally may also be used as outcome measures would represent substantial progress away from the current ambiguous classification. Based on the fastest possible walking speed on the NMPK, the studies reviewed have demonstrated a huge patient variability within the MFCL-2 mobility grade. Performance-based tests might therefore also help indicate clinically meaningful improvements within a functional classification level that are inevitably missed today.

Across the studies, there was an interesting relationship between the maximum walking speed on the NMPKs 
as a validated indicator of the overall walking capabilities [97] and the improvements in activities of community ambulation on the one hand and in indoor ADLs on the other. While improvements in activities of community ambulation have been demonstrated across the entire MFCL-2 mobility range [21,31,100-101], improvements in performance in indoor ADLs have only been shown for higher-functioning individuals within the MFCL-2 mobility spectrum, capable of walking at fast velocities of about 2.8 to $4.5 \mathrm{~km} / \mathrm{h}$ [98]. This discrepancy may be explained by the difference in accommodation time between the trials, which was 3 mo on average in the studies that investigated community ambulation and only as short as 1 wk in the study of indoor ADLs. It could well be that lower-functioning individuals need more time and training to adapt to a prosthetic intervention than higher-functioning subjects and that the results of the latter might have further improved with longer accommodation $[27,34,109]$. Comparing the statistical and individual results in the various subgroups, Theeven et al. stressed the importance of an individual patient assessment because some individuals of the high subgroup did not improve their performance on either MPK whereas some subjects of the low subgroup did [98].

As for safety of prosthesis use, the improvement in performance-based function and mobility outcomes can be explained by the differences in technology between the prosthetic knees. Many ADLs in the house and activities of community ambulation such as sitting down and walking on slopes, on stairs, on uneven terrain, and over obstacles are physiologically performed by nondisabled subjects with knee flexion during weight-bearing. In subjects with a TFA, this control must be provided by the prosthetic knee. The knee mechanisms typically fitted in limited community ambulators have in common that they do not allow for knee flexion during weight-bearing (yielding). Therefore, consider that the assignment of an individual to the MFCL-2 mobility grade and the commonly consequent selection of prosthetic componentry may technically restrict the achievable mobility of a part of this population. Knee flexion during weight-bearing (yielding) is only permitted by hydraulic stance control knees [16-19,22,106-108]. Based on technical considerations [16-19,22,106-108] and one older study [110], MFCL-2 subjects are hardly able to safely control the switching mechanisms of hydraulic NMPKs. Meanwhile, sensor input and MP control have overcome the physical challenges to safely use hydraulic knees. As the results of the studies reviewed have consistently shown, the hydraulic default stance MPKs C-Leg and C-Leg Compact may enable individuals with a TFA and MFCL-2 mobility grade to execute activities of community ambulation, as well as indoor ADLs, better and faster while increasing safety of prosthesis use at the same time. These findings are consistent with those for individuals with MFCL-3 mobility grade [23].

In addition, those individuals who are capable of walking at a faster velocity of more than $2.9 \mathrm{~km} / \mathrm{h}(0.8 \mathrm{~m} / \mathrm{s})$ on their NMPK tend to benefit more from the C-Leg than from the C-Leg Compact [98]. This might be explained by the fact that patients who walk faster are also more likely to walk with a broader range of walking speeds, thus possibly taking advantage of the additional MP hydraulic swing control of the C-Leg rather than of the conventional hydraulic swing control of the C-Leg Compact.

\section{Perceived Function and Satisfaction}

Somewhat unexpectedly, the improvements in perceived function and mobility as assessed by self-reported outcome measures for use of an MPK lag behind the performance-based improvements. Only 22 percent of the self-reported outcome measures related to function, mobility, and satisfaction showed a significant improvement as a result of MPK use, mainly in the higher-functioning subset of the MFCL-2 mobility range for indoor ADLs. Note, however, that the perceived difficulty to perform the ADLs investigated in Theeven et al. was relatively low across all subgroups, even when using a NMPK, leaving not much room for further improvement [98]. For the lower-functioning, slower-walking subset of the MFCL-2 mobility range, only Burnfield et al. reported a significant increase in the PEQ Mobility scale [100], but the reported increase was twice as big as the MDC as reported by Resnik and Borgia [105]. This means that MFCL-2 individuals, especially at the lower end of the studied mobility spectrum, experience greater improvements in objective performance by MPK use than they subjectively acknowledge. In contrast, the two studies that asked the subjects for their personal prosthesis preference found that 90 percent of patients preferred the MPK over their previous NMPK [31,98]. The explanation for this discrepancy between the limited perceived functional improvements and the clear prosthetic knee preference may be found in the far better improvement of perceived safety of prosthesis use with either MPK as discussed previously. 


\section{Recommendation for Practice}

The results of this systematic review suggest that the use of MP hydraulic stance only or MP stance and swing control prosthetic knees may improve safety, function, and mobility of limited community ambulators with unilateral TFA. In light of these findings, it no longer appears appropriate to generally withhold this advanced prosthetic technology from MFCL-2 individuals. On the other hand, the current state of the research does not justify fit of an MPK in all limited community ambulators. But even high-quality clinical research with RCTs only allows for conclusions on the basis of means and averages of the studied population but not on an individual patient [111]. Several European healthcare systems, e.g., in Germany, Austria, the Netherlands, Italy, and France, have addressed the issue of individual decision-making in prosthetics by allowing trial fittings to study whether an individual patient benefits from an MPK intervention, as supported by the findings of Theeven et al. [98]. Many factors contribute to the success or failure of prosthetic interventions, including the actual everyday mobility needs, the basic physical capabilities, and the personal objectives and motivation of the patient [112]. Based on the clinical studies analyzed in the present systematic review, the following suggestions for preliminary qualifying and decision-making criteria can be made:

1. Patients who walk less than $60 \mathrm{~m}(195 \mathrm{ft})$ on their NMPK in the 2MWT, which equals an average walking speed of less than $1.8 \mathrm{~km} / \mathrm{h}(1.1 \mathrm{mph})$, have not yet been studied with MPK interventions. That does not necessarily mean that these patients disqualify for an MPK trial fitting, but no research-based suggestions or recommendations for this patient group can be given.

2. Patients who are capable of walking between 60 and $95 \mathrm{~m}$ (195 to $310 \mathrm{ft}$ ) in the 2MWT on their NMPK, which equals an average walking speed between 1.8 and $2.9 \mathrm{~km} / \mathrm{h}$ (1.1-1.8 $\mathrm{mph}$ ) may benefit from using an MPK for safety and to improve the abilities required for community ambulation. Their walking speed and ability to vary walking velocity suggests that MP swing control may not necessarily be required; therefore, a trial fitting with the MP stance controlled C-Leg Compact may be considered.

3. Patients who are able to walk more than $95 \mathrm{~m}$ (310 ft) in the 2MWT on their NMPK, which equals a walking speed of faster than $2.9 \mathrm{~km} / \mathrm{h}(1.8 \mathrm{mph})$ may benefit from using an MPK for safety, community ambula- tion, and indoor ADLs. Their higher walking speed is likely to result in a higher ability to vary walking velocities and may therefore justify a trial fitting with the MP stance and swing controlled C-Leg.

After appropriate training and accommodation, the patient should demonstrate an improvement in the distance walked in the 2MWT as a validated outcome measure for the overall walking capabilities and mobility $[104,113]$. The MDC in subjects with a lower-limb amputation has been reported to be between $17 \mathrm{~m} \mathrm{(56 \textrm {ft } )}$

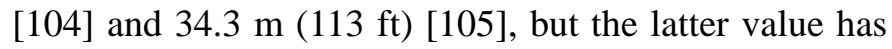
been established for mixed groups of higher-functioning subjects with transtibial amputation and TFA. In elderly, nonamputated, prefrail, and frail subjects; patients with stroke; and patients with hip fracture, improvements in short-distance $(3-10 \mathrm{~m})$ walking speed of $0.1 \mathrm{~m} / \mathrm{s}$ are considered clinically meaningful [114-119] and correlate with the risk of falling [120], frailty [121], and even survival [122-123]. We therefore believe that a minimum improvement in average walking speed in the 2MWT of $0.1 \mathrm{~m} / \mathrm{s}$, which would result in an increase in the distance walked of at least $12 \mathrm{~m}$ (40 ft), may also be considered clinically meaningful and justify the use of an MPK in individuals with a TFA and MFCL-2 mobility grade. In addition, an improvement in the TUG exceeding the MDC of 3.6 s [105], preferably under the cutoff value of 19 s that indicates a risk of multiple falls in subjects with transtibial amputation, may be considered a clinically relevant improvement in prosthesis safety [62]. Likewise, an improvement of perceived balance on the ABC [6$7,66]$ indicates improved confidence in prosthesis use. An MDC for the ABC score in subjects with an amputation has not yet been established, but an improvement over the cutoff value of 67 for a low risk of falling may be considered clinically relevant.

In everyday practice, the AMP is increasingly used to objectify the determination of the functional level of an individual with a lower-limb amputation [69]. Unfortunately, none of the studies reviewed used the AMP, neither to determine the functional level nor as an outcome measure. However, based on the published research on the AMP [69,105], an improvement of the score that exceeds the MDC of 3.4 points [105] may also be considered clinically meaningful. Further research with more patients and improved methodological quality is warranted to corroborate and refine or revise these preliminary suggestions. 


\section{Limitations}

This systematic review has several limitations. Although the literature search strategy and the medical databases searched were quite comprehensive, it is possible that not all existing clinical studies and publications on the effects of MPK use in the limited community ambulator population have been identified. Also, the restriction on English- and German-language publications may have resulted in missing important studies on this subject published in other languages. Moreover, a publication bias toward favorable results of the use of the MPKs cannot fully be excluded.

The relatively low total patient number of 57 limited community ambulators and especially the low number of individuals with a dysvascular amputation is a limitation of this systematic review. There is some evidence, however, that many of these individuals may belong to the very low-functioning segment of the MFCL-2 mobility spectrum that has not yet been studied with MPK interventions [104]. The challenges to prosthetic research in this population became obvious in Theeven et al. in that only 40 percent of patients who met the inclusion criteria agreed to participate and almost all of the dropouts had been subjects with a dysvascular amputation [98-99]. Nevertheless, future research will have to address the specific conditions and needs of that population.

Also, grouping study results according to the fastest possible walking speed and basing the recommendations for preliminary qualifying and decision-making criteria for trial fittings has limitations. Only one study [98-99] used the 2MWT to determine walking speed. One study [31] used the $75 \mathrm{~m}$ fastest possible walking speed on level ground test that, when analyzing the completion times, comes close to the 2MWT; one study [100-101] only reported the walking speed measured during motion capture in the gait laboratory; and one study did not report any walking speed at all [21]. Hafner and Smith, however, reported individual AMP values that indicated that the patients belonged to the intermediate- and highfunctioning MFCL-2 mobility segment [21]. It seems likely that some of the patients in the motion analysis study may not be able to maintain the walking speed measured in the gait laboratory as the average walking velocity in the 2MWT [100-101]. We therefore believe that patients who walk less than $60 \mathrm{~m}(195 \mathrm{ft})$ in the 2MWT should not generally be excluded from MPK trial fittings. However, in light of the consistent results of this systematic review, it seems appropriate to make MPK trial fittings available to the higher-functioning subset of limited community ambulators first. This approach also complies with the current paradigm that a certain basic physical fitness is required to likely benefit from using an MPK.

\section{CONCLUSIONS}

The results of this systematic review of clinical trials on interventions with MPKs in individuals with a unilateral TFA and MFCL-2 mobility grade suggest that these subjects may significantly reduce the number of falls and their risk of falling, improve their balance, and better perform activities of community ambulation that are actually categorized as part of the MFCL-3 mobility grade. Because these results have been derived from studies with low to moderate methodological quality in a yet limited number of patients, trial fittings with different types of MPKs (MP stance only or MP stance and swing control) may be considered to evaluate whether an individual benefits from using an MPK compared with NMPKs usually prescribed for MFCL-2 individuals. Criteria for appraising success or failure of the trial fitting based on the 2MWT, AMP, TUG, and ABC have been suggested. Given the challenges to objectify the current general and ambiguous definitions of the MFCLs, an evidence-based and unambiguously quantifiable functional classification or one or more validated outcome measures to corroborate the classification would help better define patient groups to be subjected to clinical research and sharpen coverage and reimbursement criteria.

\section{ACKNOWLEDGMENTS}

\section{Author Contributions:}

Drafting of manuscript: A. Kannenberg, B. Zacharias, E. Pröbsting.

Financial Disclosures: All authors are employees of Otto Bock HealthCare LP (Austin, Texas) or Otto Bock HealthCare GmbH (Duderstadt, Germany), the manufacturers of the two MPKs subject to all studies reviewed. The company did not influence the design and execution of the study nor the interpretation of the study results.

Funding/Support: Otto Bock HealthCare allowed the authors to work on the article during their regular working hours and use the company's office equipment (computers, Internet access, etc.). 


\section{REFERENCES}

1. Dillingham TR, Pezzin LE, MacKenzie EJ. Limb amputation and limb deficiency: Epidemiology and recent trends in the United States. South Med J. 2002;95(8):875-83. [PMID:12190225]

2. Davies B, Datta D. Mobility outcome following unilateral lower limb amputation. Prosthet Orthot Int. 2003;27(3): 186-90. [PMID:14727699] http://dx.doi.org/10.1080/03093640308726681

3. Robbins CB, Vreeman DJ, Sothmann MS, Wilson SL, Oldridge NB. A review of the long-term health outcomes associated with war-related amputation. Mil Med. 2009; 174(6):588-92. [PMID:19585770] http://dx.doi.org/10.7205/MILMED-D-00-0608

4. Norvell DC, Czerniecki JM, Reiber GE, Maynard C, Pecoraro JA, Weiss NS. The prevalence of knee pain and symptomatic knee osteoarthritis among veteran traumatic amputees and nonamputees. Arch Phys Med Rehabil. 2005;86(3):487-93. [PMID:15759233] http://dx.doi.org/10.1016/j.apmr.2004.04.034

5. Buckley JG, O’Driscoll D, Bennett SJ. Postural sway and active balance performance in highly active lower-limb amputees. Am J Phys Med Rehabil. 2002;81(1):13-20. [PMID:11807327] http://dx.doi.org/10.1097/00002060-200201000-00004

6. Miller WC, Deathe AB, Speechley M. Psychometric properties of the Activities-specific Balance Confidence Scale among individuals with a lower-limb amputation. Arch Phys Med Rehabil. 2003;84(5):656-61.

[PMID:12736877] http://dx.doi.org/10.1016/S0003-9993(02)04807-4

7. Miller WC, Deathe AB. A prospective study examining balance confidence among individuals with lower limb amputation. Disabil Rehabil. 2004;26(14-15):875-81. [PMID:15497916] http://dx.doi.org/10.1080/09638280410001708887

8. Miller WC, Speechley M, Deathe B. The prevalence and risk factors of falling and fear of falling among lower extremity amputees. Arch Phys Med Rehabil. 2001;82(8): 1031-37. [PMID:11494181] http://dx.doi.org/10.1053/apmr.2001.24295

9. Miller WC, Deathe AB, Speechley M, Koval J. The influence of falling, fear of falling, and balance confidence on prosthetic mobility and social activity among individuals with a lower extremity amputation. Arch Phys Med Rehabil. 2001;82(9):1238-44. [PMID:11552197] http://dx.doi.org/10.1053/apmr.2001.25079

10. Hof AL, van Bockel RM, Schoppen T, Postema K. Control of lateral balance in walking. Experimental findings in normal subjects and above-knee amputees. Gait Posture. 2007;25(2):250-58. [PMID:16740390] http://dx.doi.org/10.1016/j.gaitpost.2006.04.013
11. Stepien JM, Cavenett S, Taylor L, Crotty M. Activity levels among lower-limb amputees: Self-report versus step activity monitor. Arch Phys Med Rehabil. 2007;88(7): 896-900. [PMID:17601471] http://dx.doi.org/10.1016/j.apmr.2007.03.016

12. Genin JJ, Bastien GJ, Franck B, Detrembleur C, Willems PA. Effect of speed on the energy cost of walking in unilateral traumatic lower limb amputees. Eur J Appl Physiol. 2008;103(6):655-63. [PMID:18478251] http://dx.doi.org/10.1007/s00421-008-0764-0

13. van Velzen JM, van Bennekom CA, Polomski W, Slootman JR, van der Woude LH, Houdijk H. Physical capacity and walking ability after lower limb amputation: A systematic review. Clin Rehabil. 2006;20(11):999-1016. [PMID:17065543] http://dx.doi.org/10.1177/0269215506070700

14. Ziegler-Graham K, MacKenzie EJ, Ephraim PL, Travison TG, Brookmeyer R. Estimating the prevalence of limb loss in the United States: 2005 to 2050. Arch Phys Med Rehabil. 2008;89(3):422-29. [PMID:18295618] http://dx.doi.org/10.1016/j.apmr.2007.11.005

15. National Limb Loss Information Center [Internet]. Amputation statistics by cause: Limb loss in the United States. Knoxville (TN): Amputee Coalition of America; 2008 [cited 2013 Nov 11]. Available from: http://www. amputee-coalition.org/fact sheets/amp stats cause.pdf

16. Michael JW. Modern prosthetic knee mechanisms. Clin Orthop Relat Res. 1999;361(361):39-47.

[PMID:10212594] http://dx.doi.org/10.1097/00003086-199904000-00006

17. Huang ME, Levy CE, Webster JB. Acquired limb deficiencies. 3. Prosthetic components, prescriptions, and indications. Arch Phys Med Rehabil. 2001;82(3 Suppl 1): S17-24. [PMID:11239332] http://dx.doi.org/10.1016/S0003-9993(01)80032-0

18. Jamieson SC, Davies AJ. Prosthetics. In: Brammers CM, Spires SC, editors. Manual for clinical problems in physical medicine and rehabilitation. Philadelphia (PA): Hanley \& Belfus; 2001. p. 409-20.

19. Nelson VS, Flood KM, Bryant PR, Huang ME, Pasquina PF, Roberts TL. Limb deficiency and prosthetic management. 1. Decision making in prosthetic prescription and management. Arch Phys Med Rehabil. 2006;87(3 Suppl 1): S3-9. [PMID:16500187] http://dx.doi.org/10.1016/j.apmr.2005.11.022

20. Region B medical supplier bulletin. DMEPOS bulletin 95-01. 1995 Jan.

21. Hafner BJ, Smith DG. Differences in function and safety between Medicare Functional Classification Level-2 and -3 transfemoral amputees and influence of prosthetic knee joint control. J Rehabil Res Dev. 2009;46(3):417-33. [PMID:19675993] http://dx.doi.org/10.1682/JRRD.2008.01.0007 
22. Blumentritt S. Biomechanische aspekte zur indikation von prothesenkniegelenken [Biomechanical aspects of the indications of prosthetic knee joints]. Orthopädie-Technik. 2004;55(6):508-24. German.

23. Sawers AB, Hafner BJ. Outcomes associated with the use of microprocessor-controlled prosthetic knees among individuals with unilateral transfemoral limb loss: A systematic review. J Rehabil Res Dev. 2013;50(3):273-314. [PMID:23881757] http://dx.doi.org/10.1682/JRRD.2011.10.0187

24. Bellmann M, Schmalz T, Blumentritt S. Comparative biomechanical analysis of current microprocessor-controlled prosthetic knee joints. Arch Phys Med Rehabil. 2010; 91(4):644-52. [PMID:20382300]

http://dx.doi.org/10.1016/j.apmr.2009.12.014

25. Blumentritt S, Schmalz T, Jarasch R. The safety of C-leg: Biomechanical tests. J Prosthet Orthot. 2009;21(1):2-15. http://dx.doi.org/10.1097/JPO.0b013e318192e96a

26. Berry D, Olson MD, Larntz K. Perceived stability, function, and satisfaction among transfemoral amputees using microprocessor and non-microprocessor controlled prosthetic knees: A multicenter survey. J Prosthet Orthot. 2009;21(1):32-42. http://dx.doi.org/10.1097/JPO.0b013e318195b1d1

27. Kaufman KR, Levine JA, Brey RH, Iverson BK, McCrady SK, Padgett DJ, Joyner MJ. Gait and balance of transfemoral amputees using passive mechanical and microprocessor-controlled prosthetic knees. Gait Posture. 2007;26(4):489-93. [PMID:17869114]

http://dx.doi.org/10.1016/j.gaitpost.2007.07.011

28. Mâaref K, Martinet N, Grumillier C, Ghannouchi S, André JM, Paysant J. Kinematics in the terminal swing phase of unilateral transfemoral amputees: Microprocessor-controlled versus swing-phase control prosthetic knees. Arch Phys Med Rehabil. 2010;91(6):919-25. [PMID:20510984] http://dx.doi.org/10.1016/j.apmr.2010.01.025

29. Segal AD, Orendurff MS, Klute GK, McDowell ML, Pecoraro JA, Shofer J, Czerniecki JM. Kinematic and kinetic comparisons of transfemoral amputee gait using C-Leg and Mauch SNS prosthetic knees. J Rehabil Res Dev. 2006;43(7):857-70. [PMID:17436172] | http://dx.doi.org/10.1682/JRRD.2005.09.0147

30. Schmalz T, Blumentritt S, Jarasch R. Energy expenditure and biomechanical characteristics of lower limb amputee gait: The influence of prosthetic alignment and different prosthetic components. Gait Posture. 2002;16(3):255-63. [PMID:12443950] http://dx.doi.org/10.1016/S0966-6362(02)00008-5

31. Kahle JT, Highsmith MJ, Hubbard SL. Comparison of nonmicroprocessor knee mechanism versus C-Leg on Prosthesis Evaluation Questionnaire, stumbles, falls, walking tests, stair descent, and knee preference. J Reha- bil Res Dev. 2008;45(1):1-14. [PMID:18566922]

http://dx.doi.org/10.1682/JRRD.2007.04.0054

32. Seymour R, Engbretson B, Kott K, Ordway N, Brooks G, Crannell J, Hickernell E, Wheeler K. Comparison between the C-leg microprocessor-controlled prosthetic knee and non-microprocessor control prosthetic knees: A preliminary study of energy expenditure, obstacle course performance, and quality of life survey. Prosthet Orthot Int. 2007;31(1):51-61. [PMID:17365885] http://dx.doi.org/10.1080/03093640600982255

33. Highsmith MJ, Kahle JT, Miro RM, Mengelkoch LJ. Ramp descent performance with the C-Leg and interrater reliability of the Hill Assessment Index. Prosthet Orthot Int. 2013;37(5):362-68. [PMID:23327837] http://dx.doi.org/10.1177/0309364612470482

34. Hafner BJ, Willingham LL, Buell NC, Allyn KJ, Smith DG. Evaluation of function, performance, and preference as transfemoral amputees transition from mechanical to microprocessor control of the prosthetic knee. Arch Phys Med Rehabil. 2007;88(2):207-17. [PMID:17270519] http://dx.doi.org/10.1016/j.apmr.2006.10.030

35. Schmalz T, Blumentritt S, Marx B. Biomechanical analysis of stair ambulation in lower limb amputees. Gait Posture. 2007;25(2):267-78. [PMID:16725325] http://dx.doi.org/10.1016/j.gaitpost.2006.04.008

36. Highsmith MJ, Kahle JT, Bongiorni DR, Sutton BS, Groer S, Kaufman KR. Safety, energy efficiency, and cost efficacy of the C-Leg for transfemoral amputees: A review of the literature. Prosthet Orthot Int. 2010;34(4): 362-77. [PMID:20969495] http://dx.doi.org/10.3109/03093646.2010.520054

37. Alemayehu B, Warner KE. The lifetime distribution of health care costs. Health Serv Res. 2004;39(3):627-42. [PMID:15149482] http://dx.doi.org/10.1111/j.1475-6773.2004.00248.x

38. Lubitz JD, Riley GF. Trends in Medicare payments in the last year of life. N Engl J Med. 1993;328(15):1092-96. [PMID:8455667] http://dx.doi.org/10.1056/NEJM199304153281506

39. Hoover DR, Crystal S, Kumar R, Sambamoorthi U, Cantor JC. Medical expenditures during the last year of life: Findings from the 1992-1996 Medicare current beneficiary survey. Health Serv Res. 2002;37(6):1625-42. [PMID:12546289] http://dx.doi.org/10.1111/1475-6773.01113

40. Calfo S, Smith J, Zezza M. Last year of life study. Baltimore (MD): Centers for Medicare \& Medicaid Services, Office of the Actuary; 2004 [cited 2013 Oct 28]. Available from: http://www.cms.gov/Research-Statistics-Dataand-Systems/Research/ActuarialStudies/downloads/ Last_Year_of_Life.pdf

41. Limbless Statistics [Internet]. National Amputee Statistical Database (NASDAB). Edinburgh (United Kingdom): 
The Amputee Statistical Database for the United Kingdom Information Services Division, NHS Scotland; 2009 [cited 2012 Oct 10]. Available from: http://www.limblessstatistics.org/documents/Report2006-07.pdf

42. Buckley CM, O’Farrell A, Canavan RJ, Lynch AD, De La Harpe DV, Bradley CP, Perry IJ. Trends in the incidence of lower extremity amputations in people with and without diabetes over a five-year period in the Republic of Ireland. PLoS ONE. 2012;7(7):e41492. [PMID:22859991] http://dx.doi.org/10.1371/journal.pone.0041492

43. Global Lower Extremity Amputation Study Group. Epidemiology of lower extremity amputation in centres in Europe, North America and East Asia. Br J Surg. 2000; 87(3):328-37. [PMID:10718803] http://dx.doi.org/10.1046/j.1365-2168.2000.01344.x

44. Gauthier-Gagnon C, Grisé MC, Potvin D. Enabling factors related to prosthetic use by people with transtibial and transfemoral amputation. Arch Phys Med Rehabil. 1999; 80(6):706-13. [PMID:10378500] http://dx.doi.org/10.1016/S0003-9993(99)90177-6

45. Tinetti ME. Clinical practice. Preventing falls in elderly persons. N Engl J Med. 2003;348(1):42-49.

[PMID:12510042] http://dx.doi.org/10.1056/NEJMcp020719

46. Tinetti ME, Speechley M, Ginter SF. Risk factors for falls among elderly persons living in the community. N Engl J Med. 1988;319(26):1701-7. [PMID:3205267] http://dx.doi.org/10.1056/NEJM198812293192604

47. Maki BE, Holliday PJ, Topper AK. Fear of falling and postural performance in the elderly. J Gerontol. 1991; 46(4):M123-31. [PMID:2071833] http://dx.doi.org/10.1093/geronj/46.4.M123

48. Tinetti ME, Mendes de Leon CF, Doucette JT, Baker DI. Fear of falling and fall-related efficacy in relationship to functioning among community-living elders. J Gerontol. 1994;49(3):M140-47. [PMID:8169336] http://dx.doi.org/10.1093/geronj/49.3.M140

49. Speechley M, Tinetti M. Falls and injuries in frail and vigorous community elderly persons. J Am Geriatr Soc. 1991;39(1):46-52. [PMID:1987256]

50. Nevitt MC. Falls in older persons: Risk factors and prevention. In: Berg RL, Cassells JS, Stokes J, editors. The second fifty years: Promoting health and preventing disability. Washington (DC): National Academy Press; 1990. p. 263-90.

51. Bertera EM, Bertera RL. Fear of falling and activity avoidance in a national sample of older adults in the United States. Health Soc Work. 2008;33(1):54-62. [PMID:18326450] http://dx.doi.org/10.1093/hsw/33.1.54

52. Fletcher PC, Hirdes JP. Restriction in activity associated with fear of falling among community-based seniors using home care services. Age Ageing. 2004;33(3):273-79.
[PMID:15082433]

http://dx.doi.org/10.1093/ageing/afh077

53. Delbaere K, Crombez G, Vanderstraeten G, Willems T, Cambier D. Fear-related avoidance of activities, falls and physical frailty. A prospective community-based cohort study. Age Ageing. 2004;33(4):368-73. [PMID:15047574] http://dx.doi.org/10.1093/ageing/afh106

54. Kempen GI, van Haastregt JC, McKee KJ, Delbaere K, Zijlstra GA. Socio-demographic, health-related and psychosocial correlates of fear of falling and avoidance of activity in community-living older persons who avoid activity due to fear of falling. BMC Public Health. 2009;9: 170-76. [PMID:19490640] http://dx.doi.org/10.1186/1471-2458-9-170

55. Mackenzie L, Byles J, D’Este C. Validation of selfreported fall events in intervention studies. Clin Rehabil. 2006;20(4):331-39. [PMID:16719031] http://dx.doi.org/10.1191/0269215506cr947oa

56. Peel N. Validating recall of falls by older people. Accid Anal Prev. 2000;32(3):371-72. [PMID:10776852] http://dx.doi.org/10.1016/S0001-4575(99)00066-4

57. Schoppen T, Boonstra A, Groothoff JW, de Vries J, Göeken LN, Eisma WH. The Timed “up and go” test: Reliability and validity in persons with unilateral lower limb amputation. Arch Phys Med Rehabil. 1999;80(7): 825-28. [PMID:10414769] http://dx.doi.org/10.1016/S0003-9993(99)90234-4

58. Shumway-Cook A, Brauer S, Woollacott M. Predicting the probability for falls in community-dwelling older adults using the Timed Up \& Go Test. Phys Ther. 2000; 80(9):896-903. [PMID:10960937]

59. Bischoff HA, Stähelin HB, Monsch AU, Iversen MD, Weyh A, von Dechend M, Akos R, Conzelmann M, Dick W, Theiler R. Identifying a cut-off point for normal mobility: A comparison of the timed 'up and go' test in community-dwelling and institutionalised elderly women. Age Ageing. 2003;32(3):315-20. [PMID:12720619] http://dx.doi.org/10.1093/ageing/32.3.315

60. Thrane G, Joakimsen RM, Thornquist E. The association between timed up and go test and history of falls: The Tromsø study. BMC Geriatr. 2007;7:1-7. [PMID:17222340] http://dx.doi.org/10.1186/1471-2318-7-1

61. Desai A, Goodman V, Kapadia N, Shay BL, Szturm T. Relationship between dynamic balance measures and functional performance in community-dwelling elderly people. Phys Ther. 2010;90(5):748-60.

[PMID:20223944] http://dx.doi.org/10.2522/ptj.20090100

62. Dite W, Connor HJ, Curtis HC. Clinical identification of multiple fall risk early after unilateral transtibial amputation. Arch Phys Med Rehabil. 2007;88(1):109-14. 


\section{[PMID:17207685]}

http://dx.doi.org/10.1016/j.apmr.2006.10.015

63. Berg K, Wood-Dauphinee S, Williams JI. The Balance Scale: Reliability assessment with elderly residents and patients with an acute stroke. Scand J Rehabil Med. 1995;27(1):27-36. [PMID:7792547]

64. Major MJ, Fatone S, Roth EJ. Validity and reliability of the Berg Balance Scale for community-dwelling persons with lower-limb amputation. Arch Phys Med Rehabil. 2013;94(11):2194-2202. [PMID:23856150] http://dx.doi.org/10.1016/j.apmr.2013.07.002

65. Houdijk H, van Ooijen MW, Kraal JJ, Wiggerts HO, Polomski W, Janssen TW, Roerdink M. Assessing gait adaptability in people with a unilateral amputation on an instrumented treadmill with a projected visual context. Phys Ther. 2012;92(11):1452-60. [PMID:22836005] http://dx.doi.org/10.2522/ptj.20110362

66. Lajoie Y, Gallagher SP. Predicting falls within the elderly community: Comparison of postural sway, reaction time, the Berg balance scale and the Activities-specific Balance Confidence (ABC) scale for comparing fallers and nonfallers. Arch Gerontol Geriatr. 2004;38(1):11-26.

[PMID:14599700]

http://dx.doi.org/10.1016/S0167-4943(03)00082-7

67. Powell LE, Myers AM. The Activities-specific Balance Confidence (ABC) Scale. J Gerontol A Biol Sci Med Sci. 1995;50A(1):M28-34. [PMID:7814786] http://dx.doi.org/10.1093/gerona/50A.1.M28

68. Miller WC, Speechley M, Deathe AB. Balance confidence among people with lower-limb amputations. Phys Ther. 2002;82(9):856-65. [PMID:12201800]

69. Gailey RS, Roach KE, Applegate EB, Cho B, Cunniffe B, Licht S, Maguire M, Nash MS. The Amputee Mobility Predictor: An instrument to assess determinants of the lower-limb amputee's ability to ambulate. Arch Phys Med Rehabil. 2002;83(5):613-27. [PMID:11994800] http://dx.doi.org/10.1053/apmr.2002.32309

70. Datta D, Ariyaratnam R, Hilton S. Timed walking test: An all-embracing outcome measure for lower-limb amputees? Clin Rehabil. 1996;10:227-32. http://dx.doi.org/10.1177/026921559601000307

71. Brooks D, Parsons J, Hunter JP, Devlin M, Walker J. The 2-minute walk test as a measure of functional improvement in persons with lower limb amputation. Arch Phys Med Rehabil. 2001;82(10):1478-83. [PMID:11588757] http://dx.doi.org/10.1053/apmr.2001.25153

72. Theeven P, Hemmen B, Stevens C, Ilmer E, Brink P, Seelen H. Feasibility of a new concept for measuring actual functional performance in daily life of transfemoral amputees. J Rehabil Med. 2010;42(8):744-51.

[PMID:20809056] http://dx.doi.org/10.2340/16501977-0591
73. Vrieling AH, van Keeken HG, Schoppen T, Otten E, Halbertsma JP, Hof AL, Postema K. Uphill and downhill walking in unilateral lower limb amputees. Gait Posture. 2008;28(2):235-42. [PMID:18242995] http://dx.doi.org/10.1016/j.gaitpost.2007.12.006

74. Fradet L, Alimusaj M, Braatz F, Wolf SI. Biomechanical analysis of ramp ambulation of transtibial amputees with an adaptive ankle foot system. Gait Posture. 2010;32(2): 191-98. [PMID:20457526] http://dx.doi.org/10.1016/j.gaitpost.2010.04.011

75. Pelland L, McKinley P. The Montreal Rehabilitation Performance Profile: A task-analysis approach to quantify stair descent performance in children with intellectual disability. Arch Phys Med Rehabil. 2001;82(8):1106-14. [PMID:11494191] http://dx.doi.org/10.1053/apmr.2001.24225

76. Legro MW, Reiber GD, Smith DG, del Aguila M, Larsen J, Boone D. Prosthesis evaluation questionnaire for persons with lower limb amputations: Assessing prosthesisrelated quality of life. Arch Phys Med Rehabil. 1998;79(8):931-38. [PMID:9710165] http://dx.doi.org/10.1016/S0003-9993(98)90090-9

77. Franchignoni F, Giordano A, Ferriero G, Orlandini D, Amoresano A, Perucca L. Measuring mobility in people with lower limb amputation: Rasch analysis of the mobility section of the prosthesis evaluation questionnaire. $\mathrm{J}$ Rehabil Med. 2007;39(2):138-44. [PMID:17351696] http://dx.doi.org/10.2340/16501977-0033

78. Heinemann AW, Bode RK, O’Reilly C. Development and measurement properties of the Orthotics and Prosthetics Users' Survey (OPUS): A comprehensive set of clinical outcome instruments. Prosthet Orthot Int. 2003;27(3): 191-206. [PMID:14727700] http://dx.doi.org/10.1080/03093640308726682

79. Franchignoni F, Orlandini D, Ferriero G, Moscato TA. Reliability, validity, and responsiveness of the Locomotor Capabilities Index in adults with lower-limb amputation undergoing prosthetic training. Arch Phys Med Rehabil. 2004;85(5):743-48. [PMID:15129398] http://dx.doi.org/10.1016/j.apmr.2003.06.010

80. Franchignoni F, Giordano A, Ferriero G, Muñoz S, Orlandini D, Amoresano A. Rasch analysis of the Locomotor Capabilities Index-5 in people with lower limb amputation. Prosthet Orthot Int. 2007;31(4):394-404. [PMID:18050010] http://dx.doi.org/10.1080/03093640701253952

81. Panesar BS, Morrison P, Hunter J. A comparison of three measures of progress in early lower limb amputee rehabilitation. Clin Rehabil. 2001;15(2):157-71. [PMID:11330761] http://dx.doi.org/10.1191/026921501669259476 
82. Gauthier-Gagnon C, Grise MC. Tools for outcome measurement in lower limb amputation. Montreal (Canada): University of Montreal; 2001.

83. Callaghan BG, Sockalingam S, Treweek SP, Condie ME. A post-discharge functional outcome measure for lower limb amputees: Test-retest reliability with trans-tibial amputees. Prosthet Orthot Int. 2002;26(2):113-19.

[PMID:12227445]

http://dx.doi.org/10.1080/03093640208726633

84. Devlin M, Pauley T, Head K, Garfinkel S. Houghton Scale of prosthetic use in people with lower-extremity amputations: Reliability, validity, and responsiveness to change. Arch Phys Med Rehabil. 2004;85(8):1339-44. [PMID:15295762] http://dx.doi.org/10.1016/j.apmr.2003.09.025

85. Miller WC, Deathe AB, Speechley M. Lower extremity prosthetic mobility: A comparison of 3 self-report scales. Arch Phys Med Rehabil. 2001;82(10):1432-40. [PMID:11588750] http://dx.doi.org/10.1053/apmr.2001.25987

86. Hart DL. Orthotics and Prosthetics National Office Outcomes Tool (OPOT): Initial reliability and validity assessment for lower extremity prosthetics. J Prosthet Orthot. 1999;11:101-11. http://dx.doi.org/10.1097/00008526-199901140-00007

87. Ryall NH, Eyres SB, Neumann VC, Bhakta BB, Tennant A. The SIGAM mobility grades: A new population-specific measure for lower limb amputees. Disabil Rehabil. 2003; 25(15):833-44. [PMID:12851094] http://dx.doi.org/10.1080/0963828021000056460

88. Gallagher P, Maclachlan M. Development and psychometric evaluation of the Trinity Amputation and Prosthesis Experience Scales (TAPES). Rehabil Psychol. 2000; 45:130-54. http://dx.doi.org/10.1037/0090-5550.45.2.130

89. Gallagher P, Maclachlan M. The Trinity Amputation and Prosthesis Experience Scales and quality of life in people with lower-limb amputation. Arch Phys Med Rehabil. 2004;85(5):730-36. [PMID:15129396] http://dx.doi.org/10.1016/j.apmr.2003.07.009

90. Hofstad C, Linde H, Limbeek J, Postema K. Prescription of prosthetic ankle-foot mechanisms after lower limb amputation. Cochrane Database Syst Rev. 2004;(1):CD003978. [PMID:14974050] http://dx.doi.org/10.1002/14651858.CD003978.pub2

91. van Tulder MW, Assendelft WJ, Koes BW, Bouter LM. Method guidelines for systematic reviews in the Cochrane Collaboration Back Review Group for Spinal Disorders. Spine. 1997;22(20):2323-30. [PMID:9355211] http://dx.doi.org/10.1097/00007632-199710150-00001

92. Verhagen AP, de Vet HC, de Bie RA, Kessels AG, Boers M, Bouter LM, Knipschild PG. The Delphi list: A criteria list for quality assessment of randomized clinical trials for conducting systematic reviews developed by Delphi consensus. J Clin Epidemiol. 1998;51(12):1235-41.

[PMID:10086815]

http://dx.doi.org/10.1016/S0895-4356(98)00131-0

93. Downs SH, Black N. The feasibility of creating a checklist for the assessment of the methodological quality both of randomised and non-randomised studies of health care interventions. J Epidemiol Community Health. 1998;52(6): 377-84. [PMID:9764259]

http://dx.doi.org/10.1136/jech.52.6.377

94. Reisch JS, Tyson JE, Mize SG. Aid to the evaluation of therapeutic studies. Pediatrics. 1989;84(5):815-27. [PMID:2797977]

95. Zaza S, Carande-Kulis VG, Sleet DA, Sosin DM, Elder RW, Shults RA, Dinh-Zarr TB, Nichols JL, Thompson RS; Task Force on Community Preventive Services. Methods for conducting systematic reviews of the evidence of effectiveness and economic efficiency of interventions to reduce injuries to motor vehicle occupants. Am J Prev Med. 2001;21(4 Suppl):23-30.

[PMID:11691559] http://dx.doi.org/10.1016/S0749-3797(01)00379-8

96. Samuelsson KA, Töytäri O, Salminen AL, Brandt A. Effects of lower limb prosthesis on activity, participation, and quality of life: A systematic review. Prosthet Orthot Int. 2012;36(2):145-58. [PMID:22307861] http://dx.doi.org/10.1177/0309364611432794

97. Gremeaux V, Damak S, Troisgros O, Feki A, Laroche D, Perennou D, Benaim C, Casillas JM. Selecting a test for the clinical assessment of balance and walking capacity at the definitive fitting state after unilateral amputation: A comparative study. Prosthet Orthot Int. 2012;36(4):415-22. [PMID:22389424] http://dx.doi.org/10.1177/0309364612437904

98. Theeven P, Hemmen B, Rings F, Meys G, Brink P, Smeets $\mathrm{R}$, Seelen H. Functional added value of microprocessorcontrolled knee joints in daily life performance of Medicare Functional Classification Level-2 amputees. J Rehabil Med. 2011;43(10):906-15. [PMID:21947182]

99. Theeven PJ, Hemmen B, Geers RP, Smeets RJ, Brink PR, Seelen HA. Influence of advanced prosthetic knee joints on perceived performance and everyday life activity level of low-functional persons with a transfemoral amputation or knee disarticulation. J Rehabil Med. 2012;44(5):45461. [PMID:22549656] http://dx.doi.org/10.2340/16501977-0969

100. Burnfield JM, Eberly VJ, Gronely JK, Perry J, Yule WJ, Mulroy SJ. Impact of stance phase microprocessorcontrolled knee prosthesis on ramp negotiation and community walking function in K2 level transfemoral amputees. Prosthet Orthot Int. 2012;36(1):95-104. 


\section{[PMID:22223685]}

http://dx.doi.org/10.1177/0309364611431611

101. Eberly VJ, Mulroy SJ, Gronley JK, Perry J, Yule WJ, Burnfield JM. Impact of a stance phase microprocessorcontrolled knee prosthesis on level walking in lower functioning individuals with a transfemoral amputation. Prosthet Orthot Int. 2014;38(6):447-55. [PMID:24135259] http://dx.doi.org/10.1177/0309364613506912

102. Wetz HH, Hafkemeyer U, Drerup B. Einfluss des C-LegKniegelenk-Passteiles der Fa. Otto Bock auf die Versorgungsqualität Oberschenkelamputierter. Eine klinischbiomechanische Studie zur Eingrenzung von Indikationskriterien [The influence of the C-Leg knee shin system of Otto Bock on the care of above-knee amputees: A clinical biomechanical study to define indications]. Orthopade. 2005;34(4):298-319. German. [PMID:15812621] http://dx.doi.org/10.1007/s00132-005-0783-z

103. van der Linde H, Hofstad CJ, Geurts AC, Postema K, Geertzen JH, van Limbeek J. A systematic literature review of the effect of different prosthetic components on human functioning with a lower-limb prosthesis. J Rehabil Res Dev. 2004;41(4):555-70. [PMID:15558384] http://dx.doi.org/10.1682/JRRD.2003.06.0102

104. Devlin M, Sinclair LB, Colman D, Parsons J, Nizio H, Campbell JE. Patient preference and gait efficiency in a geriatric population with transfemoral amputation using a free-swinging versus a locked prosthetic knee joint. Arch Phys Med Rehabil. 2002;83(2):246-49.

[PMID:11833030]

http://dx.doi.org/10.1053/apmr.2002.27464

105. Resnik L, Borgia M. Reliability of outcome measures for people with lower-limb amputations: Distinguishing true change from statistical error. Phys Ther. 2011;91(4):555-65. [PMID:21310896] http://dx.doi.org/10.2522/ptj.20100287

106. Seymour R. Prosthetics and orthotics: Lower limb and spinal. Philadelphia (PA): Lippincott Williams \& Wilkins; 2002.

107. Radcliffe CW. The Knud Jansen Lecture: Above-knee prosthetics. Prosthet Orthot Int. 1977;1(3):146-60. [PMID:617371]

108. Radcliffe CW. Four-bar linkage prosthetic knee mechanisms: Kinematics, alignment and prescription criteria. Prosthet Orthot Int. 1994;18(3):159-73. [PMID:7724349]

109. Highsmith MJ. Microprocessor knees: Considerations for accommodation and training. J Prosthet Orthot. 2013; 25(4S):60-64.

http://dx.doi.org/10.1097/JPO.0b013e3182a891b5

110. Isakov E, Susak Z, Becker E. Energy expenditure and cardiac response in above-knee amputees while using prostheses with open and locked knee mechanisms. Scand J Rehabil Med Suppl. 1985;12:108-11. [PMID:3868034]
111. Sackett DL, Rosenberg WM, Gray JA, Haynes RB, Richardson WS. Evidence based medicine: What it is and what it isn’t. BMJ. 1996;312(7023):71-72. [PMID:8555924] http://dx.doi.org/10.1136/bmj.312.7023.71

112. Morgenroth DC. Prescribing physician perspective on microprocessor-controlled prosthetic knees. J Prosthet Orthot. 2013;25(4S):53-55. http://dx.doi.org/10.1097/JPO.0b013e3182a88d02

113. Parker K, Kirby RL, Adderson J, Thompson K. Ambulation of people with lower-limb amputations: Relationship between capacity and performance measures. Arch Phys Med Rehabil. 2010;91(4):543-49. [PMID:20382285] http://dx.doi.org/10.1016/j.apmr.2009.12.009

114. Perera S, Mody SH, Woodman RC, Studenski SA. Meaningful change and responsiveness in common physical performance measures in older adults. J Am Geriatr Soc. 2006;54(5):743-49. [PMID:16696738] http://dx.doi.org/10.1111/j.1532-5415.2006.00701.x

115. Kwon S, Perera S, Pahor M, Katula JA, King AC, Groessl EJ, Studenski SA. What is a meaningful change in physical performance? Findings from a clinical trial in older adults (the LIFE-P study). J Nutr Health Aging. 2009; 13(6):538-44. [PMID:19536422] http://dx.doi.org/10.1007/s12603-009-0104-z

116. Perry J, Garrett M, Gronley JK, Mulroy SJ. Classification of walking handicap in the stroke population. Stroke. 1995;26(6):982-89. [PMID:7762050] http://dx.doi.org/10.1161/01.STR.26.6.982

117. Alley DE, Hicks GE, Shardell M, Hawkes W, Miller R, Craik RL, Mangione KK, Orwig D, Hochberg M, Resnick $\mathrm{B}$, Magaziner J. Meaningful improvement in gait speed in hip fracture recovery. J Am Geriatr Soc. 2011;59(9): 1650-57. [PMID:21883109] http://dx.doi.org/10.1111/j.1532-5415.2011.03560.x

118. Purser JL, Weinberger M, Cohen HJ, Pieper CF, Morey MC, Li T, Williams GR, Lapuerta P. Walking speed predicts health status and hospital costs for frail elderly male veterans. J Rehabil Res Dev. 2005;42(4):535-46. [PMID:16320148] http://dx.doi.org/10.1682/JRRD.2004.07.0087

119. Schmid A, Duncan PW, Studenski S, Lai SM, Richards L, Perera S, Wu SS. Improvements in speed-based gait classifications are meaningful. Stroke. 2007;38(7):2096-2100. [PMID:17510461] http://dx.doi.org/10.1161/STROKEAHA.106.475921

120. Viccaro LJ, Perera S, Studenski SA. Is timed up and go better than gait speed in predicting health, function, and falls in older adults? J Am Geriatr Soc. 2011;59(5):88792. [PMID:21410448] http://dx.doi.org/10.1111/j.1532-5415.2011.03336.x

121. Castell MV, Sánchez M, Julián R, Queipo R, Martín S, Otero Á. Frailty prevalence and slow walking speed in 
persons age 65 and older: Implications for primary care. BMC Fam Pract. 2013;14(1):86. [PMID:23782891] http://dx.doi.org/10.1186/1471-2296-14-86

122. Hardy SE, Perera S, Roumani YF, Chandler JM, Studenski SA. Improvement in usual gait speed predicts better survival in older adults. J Am Geriatr Soc. 2007;55(11): 1727-34. [PMID:17916121]

http://dx.doi.org/10.1111/j.1532-5415.2007.01413.x

123. Studenski S, Perera S, Patel K, Rosano C, Faulkner K, Inzitari M, Brach J, Chandler J, Cawthon P, Connor EB, Nevitt M, Visser M, Kritchevsky S, Badinelli S, Harris T, Newman AB, Cauley J, Ferrucci L, Guralnik J. Gait speed and survival in older adults. JAMA. 2011;305(1):50-58. [PMID:21205966]

http://dx.doi.org/10.1001/jama.2010.1923
Submitted for publication May 2, 2014. Accepted in revised form September 30, 2014.

This article and any supplementary material should be cited as follows:

Kannenberg A, Zacharias B, Pröbsting E. Benefits of microprocessor-controlled prosthetic knees to limited community ambulators: Systematic review. J Rehabil Res Dev. 2014;51(10):1469-96.

http://dx.doi.org/10.1682/JRRD.2014.05.0118

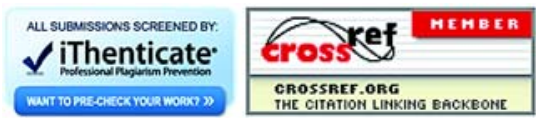


